\title{
Ortaöğretim Öğretmenlerinin Öğrenme-Öğretme Sürecinde Bilişsel Farkındalık Stratejilerini Kullanma Düzeyleri ${ }^{1}$
}

Pinar Bilasa ${ }^{2}$

Geliş Tarihi: 2017-03-22

Kabul Tarihi: 2017-07-04

\section{Öz}

$\mathrm{Bu}$ araştırma ortaöğretimde görev yapan öğretmenlerin bilişsel farkındalık stratejilerini kullanma düzeylerini belirlemek amacıyla yapılmıştır. Betimsel özellikte olan araştırmada tarama modelinden yararlanılmıştır. Veriler Yıldırım (2012) tarafından hazırlanan 44 maddelik "Bilişsel Farkındalık Stratejisi Ölçeği” ile 21-25 Mart 2016 tarihinde Mersin'de düzenlenmiş olan hizmetiçi eğitime katılan 97 ortaöğretim öğretmeninin görüşlerinden elde edilmiştir. Verilerin analizinde Kolmogorov-Smirnov Z testi, Shapiro Wilk testi, frekans, yüzde, aritmetik ortalama, ANOVA, bağımsız gruplar t testi, Mann Whitney U testi, Kuruskall Wallis H testleri kullanılmıştır. Araştırma sonucunda, öğretmenlerin mesleki kıdem sürelerinin 16-20 yıl arasında yoğunlaştı̆̆ olduğu, öğrenme-öğretme sürecinde bilişsel farkındalık stratejilerini kullanma düzeylerinin 's1k s1k' düzeyinde olduğu görülmüş̧ür.

Anahtar Sözcükler: Bilişsel farkındalık, öğretmen, öğrenme-öğretme süreci.

\footnotetext{
${ }^{1} \mathrm{Bu}$ çalışma 13-15 Mayıs 2016 tarihleri arasında gerçekleştirilen $7^{\text {th }}$ "International Conference on New Horizons in Education' da özet bildiri olarak sunulmuştur

${ }^{2}$ Dr., Gazi Üniversitesi Gazi Eğitim Fakültesi Eğitim Bilimleri Bölümü Eğitim Programları ve Öğretim Anabilim Dalı pinarbilasa@gmail.com
} 
The Usage Level of Metacognition Strategies by Secondary School Teachers in TeachıngLearning Process

Submitted by 2017-03-22

Accepted by 2017-07-04

\begin{abstract}
This research was conducted to determine the usage level of metacognition strategies by secondary education teachers. Scanning model has been used in this descriptive research. Data has been collected from the views of 97 secondary education teachers who attended to a in-service training on March 2016 in Mersin by. 44-item scale developed by Y1ldırım (2012). In the analysis of data Kolmogorov-Smirnov Z test, Shapiro Wilk test, frequency, percentage, mean, ANOVA, independent sample t test, Mann-Whitney U test, Kuruskall Wallis tests were used. As a result it was seen that, teachers' seniority period of time were between 16-20 years, most of them were graduates of faculty of education and their usage of cognitive strategies in teaching process were at 'often' level.
\end{abstract}

Key Words: Metacognition, teacher, learning-teaching process. 


\section{Giriş}

Yenidünya düzeni, kendini geliştiren ve kendine yatırım yapan insan kaynağı potansiyelini geliştirmeye teşvik etmektedir. Eğitim bireylerin, hızla değişerek çeşitlenen yaşama ayak uydurabilmeleri, bilişsel yeterliliklerinin farkına varabilmeleri ve bilişsel farkındalık becerisi kazanabilmelerinde önemli bir rol oynar.

Bireyler, belli görevleri yerine getirirken düşündüğünü fark etme ve daha sonra bu farkındalığı, yapmak istedikleri için kontrol etme (Marzano ve diğ., 1988, s. 9) şeklinde bir biliş sistemine sahiptirler. Bu durum bireye kendi düşünme ve değerlendirmesi hakkında farkındalığa sahip olma (Forrest-Pressley ve Waller, 1984, s.6) ve kendi düşüncesini düzenleme yeteneği (Wilson, 1999, s. 3) verir. Bireyin bilgisini, düşünme süreçlerini, bilişsel ve duygusal durumlarını amaçlı biçimde izleme ve düzenlemesi (Hacker, 1998, s.11), bireye daha etkili kavrayabilme ve bilişsel aktiviteleri düzenleyebilme yeteneği kazandırır (Gavelek ve Raphael, 1985, 23). Böylece birey kendi düşünmesi hakkında düşünme veya kendi bilişi hakkındaki bilgisi (Wellman, 1985, s.1) konusunda bilişsel farkındalık kazanmış olur.

Bilişsel farkındalık; en genel anlamda; 'düşünme stratejileri toplamı' (Gelen, 2003, s.32) ya da 'bilgiyi kullanma yolu' (Bedir, 1996, s.55) olarak tanımlanabilir. Bilişsel farkındalık alan yazında; 'metacognition, biliş bilgisi, biliş ötesi, metakognitif bilgi, yürütücü bilis, biliş üstü, üstbiliş, bilgiyi kullanma yolu, bilişsel farkındalık' ifadeleriyle karş1lık bulmaktadır (Yıldırım, 2012, s.3). Alan yazında bu kavramların sıklıkla birbirlerinin yerine kullanılması kavramın karmaşık, anlaşılması güç veya birbirinden farklı kavramlarmış gibi anlaşılmasına sebep olmaktadır. Bu araştırmada kolay anlaşılabilirliği sağlamak amacıyla "bilişsel fakkındalık” kavramı kullanılmıştır.

Bilişsel farkındalığın kökenini tam olarak belirlemek zor olsa da yapılan çalışmalar bu kavramın çok önceleri bazı filozof ve bilim adamları tarafından dikkate alındığını göstermektedir. Spinoza’nın (1632-1677) “... eğer birisi bir şeyi biliyorsa o halde onu bildiğini biliyordur" ifadesi ilk olarak bilişsel farkındalıktan bahsedildiğinin bir kanıtı olarak kabul edilmektedir. Platon'un, bilginin farkında olmak olduğunu ifade etmesi, Aristo'nun da eylemlere farkındalık kazandıran, işitme ve görmeden başka bağımsız bir güç olduğuna yönelik ifadeleri (Göçmen, 2003, s.85) bilişsel farkındalı̆̆ın ilk tanımları olarak kabul edilebilir. Terim olarak ise ilk kez 1970'lerin başında John Flavell tarafından bellek-ötesi (meta-memory) ifadesiyle öne sürülmüştür. Flavell'e göre; bilişsel farkındalık; bireyin, bilişsel işlemleri, çıktıları veya onlarla ilgili herhangi bir şey hakkındaki bilgisini ifade eder. 
Aynı zamanda aktif izlemeyi, sürekli düzenlemeyi ve bu süreçlerin tutarlı biçimde organizasyonunu ifade eder (Göçmen, 2003, s.85).

Bireyin düşünceleri hakkındaki fikirleri, bilgiler hakkındaki kendi bilgi ve eylemleri (Weinert, 1987, s.8) belirli stratejilerle gerçekleşmektedir. Birey bu stratejileri kullanarak özizleme yapar ve starateji kullanımına ilişkin bilinç geliştirir (Barkowski ve diğerleri, 1987: 4). Flavell, öğrenmenin tamamlanması için, bilişötesi stratejilerin “izleyici” süreçler olduğunu ileri sürmektedir (Göçmen, 2003, s.85). Bu stratejiler sayesinde birey bilinçli bir biçimde düşünür, plan yapar ve kendi kendini izleyerek bilişini düzenler.

Öğrenme-öğretme sürecinde bilişsel farkındalık, öğrencinin kavramadaki aksaklıklarının farkına varması ve bu konuda ne yapacağını bilmesinde yol gösterici olması açısından oldukça önemlidir. Bilişsel farkındalık becerisine sahip bir öğrenci, bilgi ve beceri kazanmanın çeşitli aşamalarında kendi bilişini planlama, izleme ve düzenleme yapabilme becerisine sahiptir (Lories, Dardenne ve Yzerbyt, 1998, s.81). Etkili bir şekilde farklı davranış ve becerileri yerine getiren öğrenciler için öğrenme deneyimleri gerçekleştirmelerine olanak sağlamak ve eğitim çevresindeki değişikliklerin nasıl olabileceğini öğrencilere göstermek (Ashman ve Conway, 1993, s.1) öğretmenlerin esas görevlerindendir. Öğretmenler öğretme-öğrenme sürecinde öğretimden önce, öğretim boyunca ve öğretim sonrasında öğrencilerin daha etkili öğrenmelerini sağlamak için kendi kendilerine düşünmeye ihtiyaç duyduklarını söylemektedirler. Ĕ̆er öğretmenler öğrenme-öğretme sürecinde bilişsel farkındalık stratejilerini kullanırlarsa sınıf içi iletişimi ve akademik performansı arttırabileceklerdir.

Öğrencilerin bilişsel farkındalık yeteneklerini değerlendirmek, öğrenme-öğretme sürecinde öğretimi daha etkili ve yeterli kılacaktır. Bilişsel farkındalık stratejileri bir öğretmene öğrencinin performansını izleme, değerlendirme yapma ve gerekli geri bildirimleri verebilme, onun düşündüğünü düşünmesini nasıl fark ettirme konusunda yardımcı olur. Çünkü öğrenci bir şeyi neden öğrendiğini daha iyi, nasıl öğrenebileceğini, neden doğru neden yanlış yaptığını bilmek ister. Eğer öğrenci bunları bilirse bilişötesini kullanıyor demektir. Böylece yaptığı yanlışlara benzer yanlışları tekrar yapmaktan kaçınmayı ve daha doğru stratejilere yönelmeyi seçebileceklerdir. Ayrıca öğrencilere başarılarıyla ilgili geri bildirim vermek öğretimin önemli bir parçasıdır (Hartman, 2002, s.154).

Öğrenme-öğretme sürecinde kullanılan çeşitli yöntem, teknik ve stratejiler; bilişsel farkındalıkların artmasına destek olduğundan bu süreçte öğretmenlerin önemli bir yeri olduğu kaçınılmaz bir gerçektir. Öğrenme-öğretme sürecinde, deneyimli öğretmenler, daha etkili ve 
verimli bir şekilde öğrenme aktivitelerini organize etme, planlama, karar verme ve değerlendirme amacıyla bilişsel stratejilere ihtiyaç duyarlar. Çünkü ders programlarını oluşturma ve sunma esnasında öğrenmenin öğrencilerinde nasıl meydana geldiğini göz önünde bulundurmak zorundadırlar. Bilişsel farkındalık yetenekleri öğrencilerin bilgiyi kavramalarına ve gerçek anlamda amaçlarına ulaşıp ulaşamadıklarının farkında olmalarına yardımcı olmaktadır. Aynı zamanda öğrenme görevine hâkim olup olamadıkları hakkında öğrencileri bilgilendirir (Forrest-Presley, Mckinnon, Waller, 1985, s.130).

Genel olarak öğretmenlerin, öğrenme-öğretme sürecinde sürecinde kendi deneyimleri, bilgileri doğrultusunda geliştirdikleri yöntemlerle öğrencilerin öğrenmelerine yardımcı oldukları bilinmektedir. Öğretmenler için bu stratejiler ile öğretme, öğrencilerin kendi düşünmeleri hakkında düşünmelerini sağlamak anlamına gelmektedir. Bu düşünceler öğretim amaçları, materyalleri, programla ilgili diğer konular ve öğretim ile ilgilidir. Bu şekilde düşünme; öğrenmeden önce, öğrenme boyunca ve öğrenme sonrasında öğretim verimliliğini maksimize eder. Bilişsel farkındalıkta öğrenmenin anlamı; öğretmenlerin öğrencilerin bilme ile ilgili bilişlerini geliştirecek ve harekete geçirecek öğrenmeyi nasıl sağlayacakları hakkında düşünmeleridir (Hartman, 2002, s.149).

Öğretmenlerin öğrenme-öğretme sürecinde öğrencilere bilişsel farkındalıklarını arttırabilmeleri için öncelikle kendilerinin bilişsel farkındalık becerilerini ve buna yönelik öğrenme stratejilerini bilmeleri ve kullanmaları gerekmektedir. Ancak öğretmenler kendi bilişsel düşünmelerinin ne kadar farkındadırlar ve eğitim programının öğrenme-öğretme sürecinde yani etkileşimin öğrenciyle en aktif olduğu noktada bilişsel stratejilerden nasıl yararlanmaktadırlar? sorusunun araştırılması alandaki önemli bir boşluğu dolduracaktır.

Bilişsel farkındalığa yönelik araştırmalara ilişkin ilgi ve merak giderek artmaktadır. Özellikle son yıllarda bu konuda pek çok araştırma yapıldı̆̆ı görülmektedir. Bilişsel farkındalığa yönelik artan ilginin nedeni ise; nasıl daha iyi öğrenileceğine yönelik merakın artması ve bilişsel farkındalıklarının artırıldığında öğrenme ve öğretmenin daha iyi gelişme gösterdiği yönünde yapılan araştırmaların varlığı olarak açıklanabilir. Örneğin Artzt ve Armour-Thomas'ın (1998), bilişsel farkındalık eğitimi alan öğretmenlerin problem çözmede sınıf içi aktivitelerine etkisini incelediği araştırmasında; öğretmenlerin etkinliklerinde bilişsel farkındalık stratejilerini kullanmaları ile sınıf içi performanslarında önemli derecede bir artış olduğunu gözlemlenmişlerdir (Akt.Yıldırım, 2012, s.44-45). Sönmez Ektem 'in (2007), ilköğretim beşinci sınıf matematik dersi problem çözme sürecinde uygulanan bilişsel farkındalık stratejilerinin, öğrencilerin erişilerine, yürütücü biliş becerilerine ve tutumlarına 
etkisini incelediği diğer bir araştırmada da, yürütücü biliş stratejilerinin, öğrencilerin erişilerini, yürütücü biliş becerilerini ve tutumlarını olumlu yönde etkilediğini ortaya koyduğu görülmektedir. Bir başka çalışmada da Biryukov (tarihsiz), 28 lise matematik öğretmen adayı ve 20 ilköğretim matematik öğretmen adayı üzerinde bilişsel farkındalığın problem çözme başarısına etkisini araştırmış ve bilişsel farkındalığı uygulamanın problem çözme başarısını arttırıcı önemli bir faktör olduğunu ortaya koymuştur (Akt.Öztürk, 2009, s.36). Başka bir çalışmada Gelen (2003), Hatay-Antakya merkez ilçede bulunan 33 ilköğretim okulunun yedinci sınıf öğrencileri üzerinde bilişsel farkındalığın okuduğunu anlama üzerindeki etkisini araştırmış ve bilişsel farkındalık stratejisinin Türkçe dersinde; öğrencilerin bilişsel farkındalık becerilerini, okuduğunu anlama başarısını, derse ilişkin tutumlarını olumlu yönde artırdığını ve okuduğunu anlama başarıları açısından kalıcılı̆̆ı sağladığını ortaya koymuştur. Boyacı'nın (2010) yaptığı ortaöğretim öğrencilerinin temel yetenek düzeyleri ile bilişsel farkındalık (bilişötesi) öğrenme stratejileri arasındaki ilişkiyi tespit etmeye çalıştığı araştırmasında; genel yetenek düzeyi arttıkça bilişötesi öğrenme stratejilerini kullanma düzeyinin de arttı̆̆ sonucuna ulaşmıştır. Başka bir çalışmada ise Yıldırım (2012), Tunceli il merkezine bağlı ilk ve ortaöğretim kurumunda görev yapmakta olan 371 öğretmenin, öğrenme-öğretme ortamlarında bilişsel farkındalık stratejilerini kullanma düzeylerini farklı değişkenlerle ilişkilendirerek belirlemeye çalışmış ve öğretmenlerin; cinsiyet, mesleki kıdem, görev yapılan eğitim kademesi ve öğrenci sayısı faktörlerinin, öğrenme-öğretme ortamlarında bilişsel farkındalık stratejilerini uygulama düzeylerini etkilediğini ortaya koymuştur. $\mathrm{Bu}$ ve benzeri sınıf içi performansı arttırma, okuduğunu anlamada artış, problem çözme başarısında artış ve derse ilişkin olumlu tutum geliştirme gibi olumlu araştırma sonuçlarının bilişsel farkındalığa ilişkin farklı araştırmalar yapma merakını ve ilgisini giderek arttırdığı söylenebilir.

Öğretmenlerin meslek yaşantıları içinde mesleki becerilerini arttırmak amacıyla düzenlenen hizmetiçi eğitimler, hızla değişen bilim ve teknolojiyi yakından takip edebilme olanağı sağlamaktadır. Hizmetiçi eğitimler kurumsal düzeyde Milli Eğitim Bakanlığı Hizmetiçi Eğitim Genel Müdürlüğü tarafından öğretmenlereden toplanan anketlere göre düzenlenen eğitim programlarıyla Türkiye'nin belli bölgelerinde yer alan Hizmetiçi Eğitim Enstitülerinde düzenlenmektedir. Bu çalışmada ise 21-25 Mart 2016 tarihleri arasında Milli Eğitim Bakanlığı Ortaöğretim Genel Müdürlüğü tarafından Mersin ilinde düzenlenen “Öğretme-Öğrenme Kuram ve Yaklaşımları” konulu hizmetiçi eğitime Türkiye’nin farklı bölgelerinden gelerek eğitime katılan öğretmenlerin, öğrenme-öğretme sürecinde bilişsel farkındalık stratejilerini kullanma düzeylerini belirlemek amacıyla yapılmıştır. Aynı zamanda; 
cinsiyet, mesleki kıdem, mezun olunan fakülte türü değişkenlerinin öğretmenlerin öğrenmeöğretme sürecinde kullandıkları bilişsel farkındalık stratejilerine etkisi olup olmadığı ortaya koyulmuştur.

Yapılan tarama çalışmalarında cinsiyet, mesleki kıdem ve mezun olunan fakülte değişkenlerinin bilişsel farkındalık stratejilerini kullanma düzeylerini etkilediği görülmüştür. Farklı cinsiyete sahip öğretmenlerin stratejileri kullanma tercihlerinin değiştiği, öğretmenlerin meslekte geçirdikleri süre boyunca elde ettikleri tecrübenin strateji kullanma tercihlerini etkileyebildiğini ve aldıkları eğitimin stratejileri kullanma üzerinde etki edebileceğini gösteren birden çok araştırma vardır (Baykara, 2011; Doğanay ve Demir, 2011; Onbaş1, 2015; Yıldırım, 2012). Bu nedenle bu araştırmada da cinsiyet, mesleki kıdem ve mezun olunan fakülte türü değişkenleri alınarak öğretmenlerin öğrenme-öğretme sürecinde bilişsel stratejileri kullanma durumlarını etkileme durumları belirlenmeye çalışılmıştır. Bu eğitimin seçilmesinin amacı ise Türkiye'nin çeşitli illerinden gönüllü olarak öğrenme-öğretme kuram ve yaklaşımı hizmetiçi eğitim kursuna gelen öğretmenlerin kullandıkları stratejieri tespit ederek onların kendi bilişsel farkındalık düzeylerini farketmelerini sağlamaktır. Tek bir bölgenin ya da ilin değil tüm Türkiye çapında farklı bölge ve illerde görev yapan öğretmenlerin öğrenme-öğretme sürecinde bilişsel farkındalık stratejileri kullanma düzeyleri hakkında durum tespiti yapılmış olunacak ve etkileşimli bir öğrenme-öğretme ortamı sağlanıp sağlanılmadığına ilişkin bir fikir sahibi olunacaktır. Bunun yanı sıra araştırmanın özellikle ortaöğretim alan öğretmenleri üzerinde yürütülmesinin nedeni Türkiye'de çoğunlukla bu konuda ilk ve ortaokul üzerinde çalışmalar yapılmasından kaynaklanmaktadır (Örn. Sönmez Ektem, 2007; Gelen, 2003; Yıldırım 2012). Araştırma bu özelliklerinden ötürü diğer araştırmalardan farklılık göstermektedir. Araştırma tek bir ili veya bölgeyi değil hizmetiçi eğitim aracılığıyla Türkiyenin farklı illerini temsilen gelen öğretmenleri kapsayaması bakımından alanda yapılan ilk çalışma olma özelliğindedir. Bu nedenle araştırma bulgularının alana önemli katkılar sağlayacağı düşünülmektedir.

\section{Amaç}

$\mathrm{Bu}$ araştırmanın amacı; 21-25 Mart 2016 tarihleri arasında Milli Eğitim Bakanlığı Ortaöğretim Genel Müdürlüğü tarafından Mersin ilinde düzenlenmiş olan “Öğretme-Öğrenme Kuram ve Yaklaşımları" konulu hizmetiçi eğitim kursuna Türkiye'nin farklı illerinden katılan ortaöğretim öğretmenlerinin öğrenme-öğretme sürecinde bilişsel farkındalık stratejilerini kullanma düzeylerini belirleyerek cinsiye, mesleki kıdem ve mezun olunan fakülte 
değişkenlerinin strateji kullanımına etkisini ortaya koymaktır. Bu genel amaca yönelik olarak aşağıdaki sorulara cevap aranmıştır.

1. Öğretmenlerin öğrenme-öğretme sürecinde bilişsel farkındalık stratejilerini kullanma düzeyleri nasıldır?

2. Öğretmenlerin öğrenme-öğretme sürecinde bilişsel farkındalık stratejilerini kullanma düzeyleri açısından cinsiyetlerine göre anlamlı fark var mıdır?

3. Öğretmenlerin öğrenme-öğretme sürecinde bilişsel farkındalık stratejilerini kullanma düzeyleri açısından mesleki kıdemlerine göre anlamlı bir fark var mıdır?

4. Öğretmenlerin öğrenme-öğretme sürecinde bilişsel farkındalık stratejilerini kullanma düzeyleri açısından mezun oldukları fakülte türüne göre anlamlı bir fark var midir?

\section{Sinırlılıklar}

Bu araştırma; 21-25 Mart 2016 tarihleri arasında Milli Eğitim Bakanlığı Ortaöğretim Genel Müdürlüğü tarafından Mersin ilinde düzenlenmiş olan "Öğretme-Öğrenme Kuram ve Yaklaşımları" konulu hizmetiçi eğitim kursuna katılan 97 öğretmenle ve söz konusu öğretmenlerin bilişsel farkındalık stratejilerini kullanma düzeylerine ilişkin elde edilen verilerle sinırlıdır.

\section{Yöntem}

\section{Araştırma modeli}

Araştırma, tarama modelinde betimsel bir çalışmadır. Tarama modeli bir grubun çeşitli özelliklerini belirlemek için gerekli verilerin toplanmasını kapsamaktadır. Başlıca avantajı ise, araştırmaya katılan bireylerin çeşitli özelliklerine ilişkin gerekli bilginin elde edilebilmesidir (Büyüköztürk, Akgün, Karadeniz, Demirel, Kılıç, 2016, s.14-16). Buna göre bu araştırmada öğretmenlerin öğrenme-öğretme sürecinde bilişsel farkındalık stratejilerini kullanma düzeyleri betimlenmeye çalışılmış ve cinsiyet, mesleki kıdem ve mezun olunan fakülte değişkenlerinin öğretmenlerin öğrenme-öğretme sürecinde bilişsel farkındalık stratejilerinin kullanma düzylerinde bir farklılaşma yaratıp yaratmadığına bakılmıştır.

\section{Çalışma grubu}

Araştırmanın çalışma grubunu 21-25 Mart 2016 tarihinde Mersin ilinde düzenlenmiş olan hizmetiçi eğitime katılan ortaöğretim öğretmenleri oluşturmaktadır. Bu grubun seçilmesinin nedeni öğretmenlerin Türkiye'nin dört bir yanından hizmetiçi eğitim amacıyla bir araya 
gelmesidir. $\mathrm{Bu}$ nedenle örneklemin kolay ulaş1labilir örneklem yöntemi olduğu ifade edilebilir. Hizmetiçi eğitime katılan 113 öğretmenden 97'si araştırmaya katılmaya gönüllü olmuştur. Araştırmaya katılan ortaöğretimde görev yapan öğretmenlerin; cinsiyet, mesleki kıdem, mezun oldukları fakülte türüne ilişkin veriler şöyledir.

Araştırmaya katılan öğretmenlerin \%73,02'si erkek, \%26,08'i kadındır. Cinsiyetlerine göre oranları değerlendirildiğinde; erkek öğretmenler, kadın öğretmenlerden daha fazladır. Öğretmenlerin; \%37,1'i 16-20 yıl arası, \%23,7'si 21 y1l ve üzeri, \%19,6's1 11-15 yıl aras1, \%12,4'ü 0-5 yıl arası, \%7,2'si onüçte biri 6-10 yıl arası, kıdeme sahiptir. Genel dağılıma bakıldığında; öğretmenlerin, mesleki kıdem sürelerinin 16-20 yıl arasında yoğunlaştığı görülmektedir. Mezun olunan fakülte türü incelendiğinde; öğretmenlerin \%49,5'i eğitim fakültesi, \%45,4'i fen-edebiyat fakültesi, \%5,1'i ise diğer fakültelerden (açık öğretim fakültesi $\% 1,0$ ve ilahiyat fakültesi \%4,1) mezundur. Araştırmaya katılan öğretmenlerin çoğunlukla eğitim fakültesi mezunlarından oluştuğu görülmektedir.

\section{Verilerin toplanması}

Araştırma verileri öğretmenlerin kişisel bilgileri ve öğrenme-öğretme sürecinde bilişsel farkındalık stratejilerini kullanma düzeyleriyle ilgili maddelerden oluşan ve Yıldırım (2012) tarafından hazırlanarak geçerlik-güvenirlik çalışmaları yapılan 44 maddelik "Bilişsel Farkındalık Stratejisi Ölçeği” ile toplanmıştır. 358 öğretmenden elde edilen verilere göre ölçeğin Cronbach Alpha güvenirlik katsayısı .92 olarak belirlenmiştir. Bu araştırma için 97 öğretmenden elde edilen verilere gore ölçeğin Cronbach Alpha güvenirlik katsayısı yine .92 olarak belirlenmiştir. Ölçek; öğretmenlerin öğrenme-öğretme sürecinde bilişsel farkındalık becerilerini kullanma düzeylerini belirlemek amacıyla, 'her zaman, sık sık, bazen, nadiren, hiçbir zaman' ifadelerinden oluşan 5'li likert tipinde yapılandırılmıştır. Ölçekte yer alan ilgili maddelerin gerçekleşme düzeyini belirlemek için 'hiçbir zaman (1.00-1.80), nadiren (1.812.60), bazen (2.61-3.40), sik s1k (3.41-4.20), her zaman (4.21-5.00)' puan aralıkları esas alınmıştır. Ölçeğe uygulanan faktör analizi sonuçlarına göre, analize alınan 44 maddenin öz değeri 1'den büyük olan 12 faktör altında toplandığını tespit edilmiştir. Söz konusu boyutlar şöyledir (Yıldırım, 2012, s.57-60):

1. Strateji Planlama: Herhangi bir faaliyet öncesinde, öğretmenin kullanacağ stratejiye, karşılaşabileceği sorunlara ve hatırlanması gereken kurallara dikkat çekmeleri ve bu kuralları takip etmesidir. 
2. Soru Üretme: Öğretmenin konu alanı ne olursa olsun, öğrencilerin ders öncesi ve ders sırasında kendi kendilerine sorular oluşturarak çalışmalarına teşvik etmesi faydalıdır; öğrencilerin kendi kendilerine oluşturdukları bu sorular; derse hazırlıklı gelmelerine ve sıklıkla durup konu içeriğini anlayıp anlamadıklarını kontrol edebilmelerini sağlar.

3. Bilinçli Seçim Yapma: Öğretmen, öğrencilerinin karar verme sürecinde ve öncesinde yaptıkları seçimlerin sonuçlarını araştırmaya yardımcı olmak için bilişsel farkındalıklarını güçlendirebilir; böylece öğrenciler kendi faaliyetlerini, tercihleri arasındaki nedensel ilişkileri ve elde ettikleri sonuçları algılamada daha başarılı olurlar.

4. Birden Fazla Ölçüt ile Değerlendirme: Öğretmen, öğrencilerin üzerinde düşünmelerine neden olacak iki ya da daha fazla değerlendirme kriterine göre onların aktivitelerini kategorize ederek bilişsel farkındalıklarını artırabilir.

5. Güven Sağlama: Öğretmen, öğrencilerin iyi yaptıklarını tanımlamalarına yardımcı olur ve onları akranlarından geri bildirim almaya teşvik edebilir. Böylece öğrenciler, yaptıkları davranışların daha fazla bilincinde olur ve bu davranışlar için daha iyi olduğunu düşündüğü davranışlarını içselleştirir.

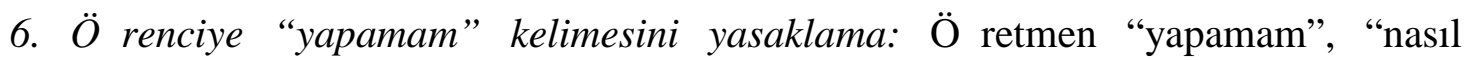
yapılacağını bilmiyorum”, “çok yavaşım” gibi bahanelerin sınıf içerisinde kabul edilemeyecek davranışlar olduğunu öğrenciye bildirmelidir. Bunun yerine öğrencilerin kendilerine; nasıl bir bilgiye ihtiyaç duyduklarını, hangi araç-gereçlerin ya da ne gibi becerilerin istenen davranışı yerine getirmede eksik olduğunu sormaları gerekir.

7. Ö̆̆rencilerin Fikirlerini Yansıtması: Öğrencilerin fikirlerinin açıklanması, geliştirilmesi, genişletilmesi, kullanılması öğrencilerin kendi düşünme sistemlerinin farkında olmasını sağlayacaktır.

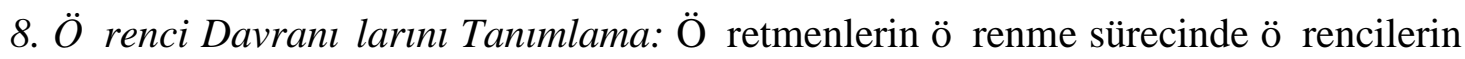
bilişsel olarak uyguladıkları yöntemlerini isimlendirmesi öğrencilerin kendi faaliyet ve davranışlarının farkında olmasını sağlar.

9. Öğrenci Terminolojisini Açı̆̆a Kavuşturma: Öğgrenciler genellikle, açık olmayan, acayip, boş kelimeler veya cümleler kullanırlar. Örneğin, öğrenciler değer yargılarını şöyle söyleyebilirler: "Haksızlık bu”. “Aşırı katı”, "Hiç iyi değil” öğretmenler bu değerleri : "Çok katı olan ne", "Ne daha adil olur" şeklinde netleştirebilirler. Bu sorular, öğrencilerin problem çözme süreçlerini açıklamak için yararlı olur. 
10. Rol Oynama/Drama Yapma: Öğrencilerin arkadaşlarının yerini alarak onların bilinçli olarak arkadaşlarının önemli karakteristik özelliklerini devam ettirmeleri sağlanır. Oyunlaştırma öğrencilerin yerini aldıkları kişinin belirli durumlar karşısında nasıl davranacağını tahmin etmelerini sağlar.

11. Günlük Tutma: Bir deneyimi ya da kişisel bir kaydı, yazmak ya da resimle ifade etmek; öğrencilerin düşünceleri ve olayları sentezlemelerine ve onları kendi sembolik formlarına dönüştürmelerine neden olur.

12. Model Olma: Tüm öğretim teknikleri; model bir öğretmenin öğrencilerin kimliği üzerinde etkisinin büyük bir öneme sahip olduğunu ortaya koymaktadır. Öğrenciler, çevrelerindeki yetişkinleri taklit ederek en iyi şekilde öğrenirler; öğretmen alenen bilişsel farkındalığı gösteren hareketler yaparsa, muhtemelen bilişsel farkındalık becerisine sahip öğrenciler yetiştirecektir.

Ölçeğin belirlenen on iki faktörlü yapısının geçerliliğine ilişkin ek kanıt elde etmek amacıyla aynı veriler üzerinde Mplus Programı kullanılarak Doğrulayıcı Faktör Analizi (DFA) yapılmıştır. DFA ile hesaplanan uyum istatistikleri şunlardır: $\chi^{2}$ (sd=836)=1048,81), $\left(\chi^{2} / \mathrm{df}\right)=1.25$, RMSEA=.05, CFI=.93, TLI=.93 ve her maddenin faktör yük değerleri .30' dan yüksek çıkmıştır. Hesaplanan uyum istatistikleri yöntemde belirtilen ölçüt değerlerini karşılamaktadır. Bu değerlere bakıldığında on iki faktörden oluşan ölçme modelinin maddelerle uyumu olduğu yani model veri uyumu sağlandığı görülmüştür.

\section{Verilerin analizi}

Verilerin analizinde bağımsız değişkenlere göre yapılan karşılaştırmalı analizlerin seçimi için verilerin dağılımların normal dağılıma uygunluğunun test edilmesi gerektiğinden öncelikle örneklem büyüklüğüne göre Kolmogorov-Smirnov Z testi (kişi sayısı 30 dan yukarı olanlar için) ve Shapiro Wilk (kişi sayısı 30 dan aşağı olanlar için) analizi yapılmıştır (akt. Yıldırım, 2012). Yapılan bu analizler sonucunda dağılımların normal olduğu iki ölçümlü değerlendirme boyutunda t-testi ve birden fazla ölçütle değerlendirme boyutunda ANOVA (tek yönlü varyans analizi) kullanılmıştır. Dağılımın normal olmadığı durumlarda ise parametrik olmayan testlerden Mann Whitney U-Testi (t-testinin parametrik olmayan karşılığı) ve Kruskal Wallis H-Testi (tek yönlü ANOVA’nın parametrik olmayan karşılığı) kullanılmıştır. Normalllik dağılımının sağlanmadığı ve kişi sayısının 30 dan daha küçük olduğu yerlerde iki grubun karşılaştırılmasında t-testi yerine parametrik olmayan Mann Whitney U-Testi kullanılmıştır. Birden fazla guba ilişkin dağılımın karşılaştırılması sonucu gruplar arasında 
anlamlı bir fark bulunması durumunda farklılığın kaynağını tespit etmek için ise KruskalWallis H-Testi kullanılnıştır.

\section{Bulgular}

Bu bölümde, alt amaçlar doğrultusunda yapılan analizlere ilişkin bulgulara yer verilmiştir.

Verilerin dağılımların normal dağılıma uygunluğunu test etmek için öncelikle örneklem Kolmogorov-Smirnov Z testi yapılmıştır. Sonuçlar Tablo 1'de verilmiştir.

Tablo 1. Bilişsel farkındalık strateji ölçĕ̆inin normallik dă̆ılımı

Bilişsel Farkındalık Stratejileri

\begin{tabular}{ccccc}
$\mathrm{N}$ & Kolmogorov-Smirnov Z & $\mathrm{p}$ & $\bar{X}$ & $\mathrm{ss}$ \\
\hline 97 & .08 & .13 & 3.72 & .55
\end{tabular}

Tablo 1'de görüldüğü gibi araştırmaya katılan öğretmenlerin bilişsel farkındalık stratejilerini kullanma durumlarının dağılımının normal olduğu belirlenmiştir $\left(K S_{(97)}=.08 ; p>\right.$ 0,05). Ölçeğin bütününe ilişkin olarak tüm öğretmenlerin bilişsel farkındalık düzeyi ortalaması 3.72’dir. Buna göre öğretmenlerin genel olarak öğrenme-öğretme sürecinde bilişsel farkındalık stratejilerini 'sık sık' (3.41-4.20) düzeyinde kullandıkları söylenebilir.

Onbaşı (2015, s.165), tarafından yapılan araştırmada da fen ve teknoloji öğretmenlerinin bilişsel farkındalık stratejilerini üç aşamada yani öğretim süreci öncesi, öğretim süreci içerisinde ve öğretim süreci sonrasında uyguladıkları yönündedir.

Öğretmenlerin, öğrenme-öğretme sürecinde bilişsel farkındalık stratejilerinin alt boyutlarını kullanma düzeylerine ilişkin analiz sonuçları ise Tablo 2'de verilmiştir.

Tablo 2. Ö̆̆retmenlerin bilişsel farkındalık stratejilerinin alt boyutlarını kullanma düzeyleri

\begin{tabular}{lccc}
\hline Boyutlar & \multicolumn{2}{c}{ Kolmogorov-Smirnov Z } & \multirow{2}{*}{ Medyan } \\
\cline { 2 - 3 } & $\mathrm{K}-\mathrm{S}$ & $\mathrm{p}$ & \\
\hline 1. Strateji planlama & .09 & $.02^{*}$ & 4.00 \\
\hline 2. Soru üretme & .22 & $.00^{*}$ & 3.66 \\
\hline 3. Bilinçli seçim yapma & .13 & $.00^{*}$ & 3.66 \\
\hline 4. Birden fazla ölçütle değerlendirme & .14 & $.00^{*}$ & 3.33 \\
\hline 5. Güven sağlama & .11 & $.00^{*}$ & 3.33 \\
\hline 6. Öğrenciye ‘yapamam' kelimesini yasaklama & .13 & $.00^{*}$ & 4.16 \\
\hline 7. Öğrenci fikirlerini yansitma & .10 & $.01^{*}$ & 4.00 \\
\hline 8. Öğrenci davranışlarını tanımlama & .14 & $.00^{*}$ & 4.00 \\
\hline 9. Öğrenci terminolojisini açı̆̆a çıkarma & .18 & $.00^{*}$ & 4.00 \\
\hline
\end{tabular}


Ege Eğitim Dergisi 2017 (18) 2: 527-556

Ortaöğretim Öğretmenlerinin Öğrenme-Öğretme Sürecinde Bilişsel Farkındalık Stratejilerini Kullanma Düzeyleri

\begin{tabular}{lccc}
\hline 10. Drama yapma / rol oynama & .11 & $.00^{*}$ & 3.50 \\
\hline 11. Günlük tutma & .13 & $.00^{*}$ & 2.33 \\
\hline 12. Model olma & .16 & $.00^{*}$ & 4.00 \\
\hline$* p<.05$ & & &
\end{tabular}

Tablo 2'de görüldü̆ğü gibi Kolmogorov-Smirnov Z normal dağılım testi sonucunda alt boyutlara ilişkin dağılımların normal olmadığı belirlenmiştir. Bundan dolayı grup ortalama değeri olarak Medyan esas alınmıştır. Araştırmaya katılan öğretmenlerin, en yüksek 4.16 ortanca değeri ile öğrenciye yapamam kelimesini yasaklama stratejisini 'sık s1k' düzeyinde kullandıkları en düşük 2.51 ortanca değeri ile de günlük tutma stratejisini 'nadiren' düzeyinde kullandıkları görülmektedir.

Onbaşı (2015:165), tarafından yapılan araştırmada sonucu bu bulguyu destekler niteliktedir. Araştırma da fen ve teknoloji öğretmenlerinin bilişsel farkındalık stratejilerinden “öğrenciye yapamam kelimesini yasaklama (sık sık) staratejisinin en yüksek kullanma oranına sahipken, günlük tutma (nadiren) staratejisini kullanma düzeyinin en düşük ortalamaya sahip olduğu belirtilmiştir. Diğer boyutlar değerlendirildiğinde; 1, 2, 3, 7, 8, 9, ve 12'nci boyutların 'sık sık' düzey aralığında, 4., 5. ve 10 boyutlarının 'bazen' düzeyinde kullanıldığı tespit edilmiştir.

Aşağıda, öğretmenlerin öğrenme-öğretme sürecinde bilişsel farkındalık stratejilerini kullanma düzeylerinin; cinsiyet, mesleki kıdem ve mezun olunan fakülte türü açısından farklılıklar olup olmadığına ilişkin bulgulara yer verilmiştir.

Öğretmenlerin öğrenme-öğretme sürecinde bilişsel farkındalık stratejilerini kullanma düzeylerinde cinsiyet değişkenine ilişkin anlamlı bir fark olup olmadığını belirleyebilmek için kişi sayıları dikkate alınarak öncelikle Shapiro-Wilk normal dağılım testi uygulanmış daha sonra uygun istatistiksel tekniklerle analizler yapılmıştır. Elde edilen sonuçlar şöyledir.

Tablo 3. Öğretmenlerin cinsiyete göre bilişsel farkındalık stratejilerini kullanma düzeyleri

\begin{tabular}{lcrccccc}
\hline \multirow{2}{*}{ Cinsiyet } & \multirow{2}{*}{$\mathrm{N}$} & \multicolumn{2}{c}{ Shapiro-Wilk } & \multirow{2}{*}{ Sira Ort. } & \multirow{2}{*}{ Medyan } & \multicolumn{2}{c}{ Mann Whitney U Testi } \\
\cline { 3 - 4 } & & $\mathrm{S}-\mathrm{W}$ & $\mathrm{p}$ & & & $\mathrm{U}$ & $\mathrm{p}$ \\
\hline Kadın & 26 & .97 & .75 & 49.62 & 3.70 & \multirow{2}{*}{907.00} & .89 \\
\hline Erkek & 71 & .90 & $.00^{*}$ & 48.77 & 3.79 & & \\
\hline
\end{tabular}

$* p<.05$

Öğretmenlerin cinsiyetlerine göre görüşlerini karşılaştırmak için öncelikle ShapiroWilk normal dağılım testi yapılmış ve dağılımın kadınlar arasında normal olduğu, erkekler arasında normal olmadığı belirlenmiştir. Bu nedenle iki grubun görüşleri arasında fark olma durumu parametrik olmayan Mann Whitney U testi ile karşılaştırılmış ve elde edilen sonuca 
göre grupların görüşleri arasında anlamlı bir farklılık belirlenememiştir ( $U=907,00 ; p>.05)$. Buna göre kadın öğretmenlerin daha yüksek sıra ortalamasına ulaştığı belirlenmiştir. Grupların medyanları incelendiğinde ise erkek ve kadın öğretmenlerin öğrenme-öğretme sürecinde bilişsel farkındalık stratejilerini 'sık sık' düzey aralığında kullandıkları görülmektedir. Bu bulgu Dilci ve Kaya (2012, s.263)’nın “4. ve 5. Sinıflarda Görev Yapan Sınıf Öğretmenlerinin Üstbilişsel Farkındalık Düzeylerinin Çeşitli Değişkenler Açısından ncelenmesi" başlıklı araştırmasındaki bulgu tarafından desteklenmektedir. Sınıf öğretmenleriyle yaptıkları çalışmada, cinsiyetin öğretmenlerin üstbilişsel farkındalık düzeylerini etkilemediği ortaya koymuşlardır.

Tablo 4. Öğretmenlerin cinsiyete göre alt boyutlara ilişkin bilişsel farkındalık stratejilerini kullanma düzeyleri

\begin{tabular}{|c|c|c|c|c|c|c|c|c|}
\hline \multirow{2}{*}{ Boyutlar } & \multirow{2}{*}{ Cinsiyet } & \multirow{2}{*}{$\mathrm{N}$} & \multicolumn{2}{|c|}{ Shapiro-Wilk } & \multirow{2}{*}{ Sira Ort. } & \multirow{2}{*}{ Medyan } & \multicolumn{2}{|c|}{$\begin{array}{c}\text { Mann Whitney U } \\
\text { Testi }\end{array}$} \\
\hline & & & S-W & $\mathrm{p}$ & & & $\mathrm{U}$ & $\mathrm{p}$ \\
\hline \multirow{2}{*}{ Strateji planlama } & Kadın & 26 & .95 & .34 & 48.69 & 4.00 & \multirow{2}{*}{915.00} & \multirow{2}{*}{.94} \\
\hline & Erkek & 71 & .92 & $.00 *$ & 49.11 & 4.00 & & \\
\hline \multirow[t]{2}{*}{ Soru üretme } & Kadın & 26 & .52 & $.00 *$ & 51.81 & 4.00 & \multirow{2}{*}{850.00} & \multirow{2}{*}{.54} \\
\hline & Erkek & 71 & .93 & $.00 *$ & 47.97 & 3.66 & & \\
\hline \multirow{2}{*}{ Bilinçli seçim yapma } & Kadın & 26 & .94 & .15 & 49.15 & 3.66 & \multirow{2}{*}{919.00} & \multirow{2}{*}{.97} \\
\hline & Erkek & 71 & .94 & $.00 *$ & 48.94 & 3.66 & & \\
\hline \multirow{2}{*}{$\begin{array}{l}\text { Birden fazla ölçütle } \\
\text { değerlendirme }\end{array}$} & Kadın & 26 & .96 & .38 & 47.12 & 3.16 & \multirow{2}{*}{874.00} & \multirow{2}{*}{.68} \\
\hline & Erkek & 71 & .95 & $.01 *$ & 49.69 & 3.33 & & \\
\hline \multirow{2}{*}{$\begin{array}{l}\text { Öğrenciye ‘yapamam’ } \\
\text { kelimesini yasaklama }\end{array}$} & Kadın & 26 & .95 & .32 & 45.27 & 4.16 & \multirow{2}{*}{826.00} & \multirow{2}{*}{.42} \\
\hline & Erkek & 71 & .88 & $.00 *$ & 50.37 & 4.33 & & \\
\hline \multirow{2}{*}{$\begin{array}{l}\text { Öğrenci fikirlerini } \\
\text { yansitma }\end{array}$} & Kadın & 26 & .94 & .14 & 47.46 & 3.75 & \multirow{2}{*}{883.00} & \multirow{2}{*}{.74} \\
\hline & Erkek & 71 & .93 & $.00 *$ & 49.56 & 4.00 & & \\
\hline \multirow{2}{*}{$\begin{array}{l}\text { Öğrenci } \\
\text { davranışlarını } \\
\text { tanımlama }\end{array}$} & Kadın & 26 & .93 & .08 & 51.23 & 4.12 & \multirow{2}{*}{865.00} & \multirow{2}{*}{.63} \\
\hline & Erkek & 71 & .92 & $.00 *$ & 48.18 & 4.00 & & \\
\hline \multirow{2}{*}{$\begin{array}{l}\text { Öğrenci } \\
\text { terminolojisini açı̆̆a } \\
\text { çıkarma }\end{array}$} & Kadın & 26 & .87 & $.00 *$ & 53.87 & 4.00 & \multirow{2}{*}{796.50} & \multirow{2}{*}{.29} \\
\hline & Erkek & 71 & .92 & $.00 *$ & 47.22 & 4.00 & & \\
\hline \multirow{2}{*}{$\begin{array}{l}\text { Drama yapma / Rol } \\
\text { Oynama }\end{array}$} & Kadın & 26 & .95 & .34 & 43.48 & 3.00 & \multirow{2}{*}{779.50} & 23 \\
\hline & Erkek & 71 & .92 & $.00 *$ & 51.02 & 3.50 & & .23 \\
\hline Guinliik tutma & Kadın & 26 & .52 & $.00 *$ & 53.40 & 2.33 & 80850 & 34 \\
\hline Gunıuк tutma & Erkek & 71 & .93 & $.00 *$ & 47.39 & 2.33 & 808.50 & .34 \\
\hline Model olma & Kadın & 26 & .94 & .15 & 51.81 & 4.16 & 85000 & 54 \\
\hline inioder orma & Erkek & 71 & .94 & $.00 *$ & 47.97 & 4.00 & 850.00 & .54 \\
\hline
\end{tabular}

$* p<.05$

Öğretmenlerin cinsiyete göre alt boyutlara ilişkin bilişsel farkındalık stratejilerini kullanma düzeylerini karşılaştırmak için kişi sayıları göz önünde bulundurularak ShapiroWilk testi yapılmıştır. Testin sonucunda dağılımların normal olmadığı $(p<.05)$ görülmüştür. $\mathrm{Bu}$ nedenle alt boyutlara ilişkin fark olma durumu Mann Whitney U testi ile karşılaştırılmış ve hiçbir boyutta anlamlı bir fark bulunamamıştır ( $p>.05)$. Sıra ortalamalarına bakıldığında 
strateji planlama, birden fazla ölçütle değerlendirme, öğrenciye 'yapamam' kelimesini yasaklama, öğrenci fikirlerini yansitma, drama yapma/rol oynama stratejilerinde erkek öğretmenlerin kadın öğretmenlere göre daha yüksek sıra ortalamasına ulaşmasına aradaki farkın anlamlı olmadığı belirlenmiştir. Grupların medyanları incelendiğinde; öğretmenlerin strateji planlama, bilinçli seçim yapma, öğrenci davranışlarını tanımlama, öğrenci terminolojisini açığa çıkarma stratejilerini aynı düzeyde (sık sık), öğrenciye ‘yapamam’ kelimesini yasaklama stratejisini erkek öğretmenlerin 'her zaman, kadın öğretmenlerin 'sık sık' düzeyde, drama yapma/rol oynama stratejisini erkek öğretmenlerin 'sık sık', kadın öğretmenlerin ‘bazen’ düzeyinde kullandıkları görülmüştür. Öğretmenler birden fazla ölçütle değerlendirme startejisini ‘bazen', günlük tutma stratejisini 'nadiren' düzeyinde kullanmakta, kadın öğretmenler 'soru üretme, öğrenci davranışlarını tanımlama, model olma' stratejilerini erkek öğretmenlere göre, öğrenci fikirlerini yansıtma stratejisini erkek öğretmenler kadın öğretmenlere göre 'sık sık' düzeyinde daha fazla kullanmaktadırlar. Bu araştırmadan elde edilen bulguya göre erkek öğretmenlerin öğrencilerinin birbirlerinin fikirlerini; düzeltmelerin, aktarmalarını, karşılaştırmalarını daha fazla teşvik ettikleri söylenebilir. Strateji planlama, bilinçli seçim yapma, öğrenci terminolojisini açı̆̆a çıkarma stratejilerini ise erkek ve kadın öğretmenler aynı düzeyde (sık sık) kullanmaktadırlar. Buna göre öğretmenlerin öğrencilerini, herhangi bir faaliyet öncesinde, öğretmenin kullanacağ1 stratejiye, karşılaşabileceği sorunlara dikkat çekme yönünde eşit düzeyde teşvik ettikleri söylenebilir. 'Güven sağlama' boyutunda ise cinsiyete göre dağılım normalliği sağlandığı için bağımsız gruplar t testi yapılmıştır. Elde edilen sonuçlar ise şöyledir.

Tablo 5. Güven sağlama boyutuna ilişkin cinsiyete göre $t$-testi

\begin{tabular}{llllllll}
\hline Bilişssel Farkındalık Stratejisi & Cinsiyet & $\mathrm{N}$ & $\bar{X}$ & $\mathrm{SS}$ & $\mathrm{sd}$ & $\mathrm{t}$ & $\mathrm{p}$ \\
\hline \multirow{2}{*}{ Güven sağlama } & Kadın & 26 & 3.47 & .72 & \multirow{2}{*}{93} & \multirow{2}{*}{1.15} & \multirow{2}{*}{24} \\
\cline { 2 - 6 } & Erkek & 71 & 3.26 & .79 & & & \\
\hline
\end{tabular}

Görüldügü gibi kadın ve erkek öğretmenlerin güven sağlama stratejisini kullanma düzeyleri arasında anlamlı bir farklılık bulunamamıştır $\left(t_{(93)}=1.159\right)$. Ortalamalara göre ise kadın öğretmenlerin ‘sık sık', erkek öğretmenlerin ‘bazen’ düzeyinde bu strateji kullandıkları söylenebilir.

Öğretmenlerin bilişsel farkındalık stratejilerini kullanma düzeylerinde mesleki kıdem süreleri değişkeni açısından öncelikle Shapiro-Wilk normal dağılım testi yapılmış, bazı kıdem aralıklarında (16-20 yıl ile 21 yıl ve üzeri) dağılımın normal olmadığı belirlendiği için görüşler Kruskall Wallis testi ile karşılaştırılmıştır. Elde edilen sonuçlara göre yapılan analiz çalışmaları şöyledir. 
Ege Eğitim Dergisi 2017 (18) 2: 527-556

Ortaöğretim Öğretmenlerinin Öğrenme-Öğretme Sürecinde Bilişsel Farkındalık Stratejilerini Kullanma Düzeyleri

Tablo 6. Mesleki kıdeme göre bilişsel farkındalık stratejilerinin kullanılma düzeyleri

\begin{tabular}{|c|c|c|c|c|c|c|c|c|}
\hline \multirow[t]{2}{*}{ Mesleki Kıdem } & \multirow[t]{2}{*}{$\mathrm{N}$} & \multicolumn{2}{|c|}{ Shapiro-Wilk } & \multirow[t]{2}{*}{ Sıra Ort. } & \multirow[t]{2}{*}{ Medyan } & \multicolumn{2}{|c|}{$\begin{array}{c}\text { Kruskall Wallis } \\
\text { Testi }\end{array}$} & \multirow[t]{2}{*}{ An. Fark } \\
\hline & & S-W & $\mathrm{p}$ & & & $\mathrm{X}^{2}$ & $\mathrm{p}$ & \\
\hline $0-5$ yil & 12 & .97 & .91 & 33.58 & 3.36 & \multirow{5}{*}{9.06} & \multirow{5}{*}{.06} & \multirow{5}{*}{ - } \\
\hline $6-10 \mathrm{y} 11$ & 7 & .946 & .694 & 45.21 & 3.72 & & & \\
\hline $11-15$ y1l & 19 & .931 & .179 & 53.39 & 3.81 & & & \\
\hline $16-20$ y1l & 36 & .939 & $.047 *$ & 44.94 & 3.70 & & & \\
\hline 21 y1l ve üzeri & 23 & .857 & $.004 *$ & 60.91 & 3.97 & & & \\
\hline
\end{tabular}

Görüldüğü gibi öğretmenlerin mesleki kıdemlerinin bilişsel farkındalık stratejilerini kullanma düzeyleri arasında anlamlı bir farklılık yoktur $\left(X^{2}=9.065 ; p>.05\right)$. Medyanlar incelendiğinde bilişsel stratejilerin her mesleki kıdem düzeyinde 'sık sık' kullanıldığ1 görülmüştür. $\mathrm{Bu}$ durum öğretmenlerin, bilişsel farkındalık stratejilerini her mesleki kıdem derecesinde 'sık sık' düzeyinde kullandığı şeklinde yorumlanabilir.

Öğretmenlerin mesleki kıdemlerine göre alt boyutlara ilişkin bilişsel farkındalık düzeylerini kullanma görüşlerini karşılaştırmak için Shapiro-Wilk normal dağılım testi yapılmış ve birden fazla ölçütle değerlendirme alt boyutu dışında kalan boyutlarda cinsiyete göre dağılımların bazı kıdem dönemlerinde normal olmadığı görülmüsşür. Bu nedenle söz konusu boyutlar itibariyle öğretmenlerin görüşleri arasında fark olma durumu parametrik olmayan testlerden Kruskall Wallis-H testi ile analiz edilmiş ve bulgular Tablo 7'de sunulmuştur.

Tablo 7. Mesleki kıdeme göre alt boyutlara ilişkin bilişsel farkındalık stratejilerinin kullanılma düzeyleri

\begin{tabular}{|c|c|c|c|c|c|c|c|c|c|}
\hline \multirow{2}{*}{$\begin{array}{l}\text { Bilişsel } \\
\text { Farkındalık } \\
\text { Stratejileri }\end{array}$} & \multirow{2}{*}{$\begin{array}{l}\text { Mesleki kıdem } \\
\text { süresi }\end{array}$} & \multirow[t]{2}{*}{$\mathrm{N}$} & \multicolumn{2}{|c|}{$\begin{array}{c}\text { Shapiro-Wilk } \\
\text { S-W }\end{array}$} & \multirow{2}{*}{$\begin{array}{l}\text { Sira } \\
\text { Ort. }\end{array}$} & \multirow{2}{*}{$\begin{array}{c}\text { Medya } \\
n\end{array}$} & \multicolumn{2}{|c|}{$\begin{array}{c}\text { Kruskall Wallis } \\
\text { Testi }\end{array}$} & \multirow{2}{*}{$\begin{array}{l}\text { An. } \\
\text { Fark }\end{array}$} \\
\hline & & & S-W & $\mathrm{p}$ & & & $X^{2}$ & $\mathrm{p}$ & \\
\hline \multirow{5}{*}{ Strateji planlama } & $0-5$ y1l & 12 & .97 & .97 & 40.29 & 3.75 & \multirow{5}{*}{3.76} & \multirow{5}{*}{.43} & \\
\hline & 6-10 y1l & 7 & .87 & .21 & 43.00 & 4.00 & & & \\
\hline & $11-15 \mathrm{y} 1 \mathrm{l}$ & 19 & .95 & .42 & 52.55 & 4.25 & & & \\
\hline & $16-20$ y1l & 36 & .97 & .44 & 46.36 & 3.87 & & & \\
\hline & 21 yıl ve üzeri & 23 & .81 & $.00^{*}$ & 56.57 & 4.25 & & & \\
\hline \multirow{5}{*}{ Soru üretme } & $0-5 \mathrm{y} 1 \mathrm{l}$ & 12 & .93 & .38 & 36.83 & 3.50 & \multirow{5}{*}{15.28} & \multirow{5}{*}{$.00 *$} & $1-3$ \\
\hline & 6-10 y1l & 7 & .92 & .52 & 58.29 & 4.00 & & & $1-5$ \\
\hline & $11-15$ y1l & 19 & .94 & .26 & 57.26 & 4.00 & & & $2-4$ \\
\hline & $16-20$ yil & 36 & .95 & .18 & 38.32 & 3.33 & & & $2-5$ \\
\hline & 21 yll ve üzeri & 23 & .54 & $.00 *$ & 62.41 & 4.33 & & & $\begin{array}{l}3-4 \\
4-5\end{array}$ \\
\hline \multirow{5}{*}{$\begin{array}{l}\text { Bilinçli seçim } \\
\text { yapma }\end{array}$} & $0-5$ y1l & 12 & .98 & .98 & 48.83 & 3.66 & \multirow{5}{*}{6.99} & \multirow{5}{*}{.13} & \\
\hline & $6-10 \mathrm{y} 1 \mathrm{l}$ & 7 & .93 & .60 & 46.57 & 3.33 & & & \\
\hline & $11-15 \mathrm{y} 1 \mathrm{l}$ & 19 & .94 & .29 & 59.13 & 4.00 & & & \\
\hline & $16-20 \mathrm{y} 1 \mathrm{l}$ & 36 & .93 & $.03 *$ & 40.43 & 3.33 & & & \\
\hline & 21 yıl ve üzeri & 23 & .89 & $.02 *$ & 54.87 & 4.00 & & & \\
\hline Güven sağlama & $0-5$ y1l & 12 & .95 & .75 & 50.67 & 3.33 & 1.56 & .81 & \\
\hline
\end{tabular}




\begin{tabular}{|c|c|c|c|c|c|c|c|c|c|}
\hline & $6-10$ y1l & 7 & .96 & .82 & 53.21 & 3.33 & & & \\
\hline & $11-15$ y1l & 19 & .96 & .67 & 45.58 & 3.33 & & & \\
\hline & $16-20 \mathrm{y} 1 \mathrm{l}$ & 36 & .94 & .09 & 46.26 & 3.33 & & & \\
\hline & 21 y1l ve üzeri & 23 & .86 & $.00 *$ & 53.96 & 3.66 & & & \\
\hline \multirow{5}{*}{$\begin{array}{l}\text { Öğrenciye } \\
\text { ‘yapamam’ } \\
\text { kelimesini } \\
\text { yasaklama }\end{array}$} & $0-5$ y1l & 12 & .97 & .98 & 31.71 & 3.83 & \multirow{5}{*}{8.38} & \multirow{5}{*}{.07} & \\
\hline & 6-10 y1l & 7 & .82 & .07 & 50.43 & 4.16 & & & \\
\hline & $11-15$ y1l & 19 & .96 & .57 & 57.21 & 4.33 & & & \\
\hline & $16-20 \mathrm{y} 1 \mathrm{l}$ & 36 & .90 & $.00 *$ & 45.49 & 4.08 & & & \\
\hline & 21 yıl ve üzeri & 23 & .81 & $.00 *$ & 5630 & 4.33 & & & \\
\hline \multirow{5}{*}{$\begin{array}{l}\text { Öğrenci fikirlerini } \\
\text { yansitma }\end{array}$} & $0-5$ y1l & 12 & .95 & .76 & 32.92 & 3.37 & \multirow{5}{*}{5.32} & \multirow{5}{*}{.25} & \\
\hline & 6-10 y1l & 7 & .97 & .89 & 42.79 & 3.50 & & & \\
\hline & $11-15$ y1l & 19 & .92 & .12 & 50.45 & 4.00 & & & \\
\hline & $16-20 \mathrm{y} 1 \mathrm{l}$ & 36 & .91 & $.01 *$ & 52.11 & 4.00 & & & \\
\hline & 21 y1l ve üzeri & 23 & .88 & $.01 *$ & 53.22 & 4.00 & & & \\
\hline \multirow{5}{*}{$\begin{array}{l}\text { Öğrenci } \\
\text { davranışlarını } \\
\text { tanımlama }\end{array}$} & $0-5 \mathrm{y} 1 \mathrm{l}$ & 12 & .91 & .26 & 46.17 & 4.00 & \multirow{5}{*}{1.71} & \multirow{5}{*}{.78} & \\
\hline & $6-10$ y1l & 7 & .88 & .22 & 45.14 & 4.25 & & & \\
\hline & $11-15$ y1l & 19 & .83 & $.00 *$ & 54.24 & 4.25 & & & \\
\hline & $16-20 \mathrm{y} 1 \mathrm{l}$ & 36 & .91 & $.00 *$ & 45.83 & 4.00 & & & \\
\hline & 21 y1l ve üzeri & 23 & .87 & $.00 *$ & 52.28 & 4.25 & & & \\
\hline \multirow{5}{*}{$\begin{array}{l}\text { Öğrenci } \\
\text { terminolojisini } \\
\text { açığa kavuşturma }\end{array}$} & $0-5$ y1l & 12 & .92 & .36 & 46.71 & 4.00 & \multirow{5}{*}{2.92} & \multirow{5}{*}{.57} & \\
\hline & 6-10 y1l & 7 & .91 & .45 & 40.86 & 3.50 & & & \\
\hline & $11-15$ y1l & 19 & .94 & .34 & 43.13 & 4.00 & & & \\
\hline & $16-20$ y1l & 36 & .88 & $.00 *$ & 50.32 & 4.00 & & & \\
\hline & 21 y1l ve üzeri & 23 & .81 & $.00 *$ & 55.46 & 4.00 & & & \\
\hline \multirow{5}{*}{$\begin{array}{l}\text { Drama yapma/rol } \\
\text { oynama }\end{array}$} & $0-5 \mathrm{yll}$ & 12 & .82 & $.02 *$ & 32.88 & 2.25 & \multirow{5}{*}{10.40} & \multirow{5}{*}{$.03 *$} & 1-4, \\
\hline & 6-10 y1l & 7 & .93 & .57 & 27.36 & 2.50 & & & $1-5$ \\
\hline & $11-15 \mathrm{y} 1 \mathrm{l}$ & 19 & .91 & .09 & 52.58 & 3.50 & & & $2-3$ \\
\hline & $16-20 \mathrm{y} 1 \mathrm{l}$ & 36 & .94 & .08 & 52.69 & 3.50 & & & $2-4$ \\
\hline & 21 y1l ve üzeri & 23 & .91 & $.04^{*}$ & 55.26 & 3.50 & & & $2-5$ \\
\hline \multirow{5}{*}{ Günlük tutma } & $0-5$ y1l & 12 & .87 & .06 & 36.13 & 1.66 & \multirow{5}{*}{3.85} & \multirow{5}{*}{.42} & \\
\hline & $6-10$ y1l & 7 & .88 & .23 & 53.00 & 2.66 & & & \\
\hline & $11-15$ y1l & 19 & .86 & $.01 *$ & 45.42 & 2.33 & & & \\
\hline & $16-20 \mathrm{y} 1 \mathrm{l}$ & 36 & .95 & .10 & 51.82 & 2.33 & & & \\
\hline & 21 y1l ve üzeri & 23 & .94 & .23 & 53.04 & 3.00 & & & \\
\hline \multirow{5}{*}{ Model olma } & $0-5$ y1l & 12 & .93 & .44 & 48.50 & 4.16 & \multirow{5}{*}{8.14} & \multirow{5}{*}{.08} & \\
\hline & $6-10$ y1l & 7 & .82 & .07 & 43.07 & 4.33 & & & \\
\hline & $11-15$ y1l & 19 & .81 & $.00 *$ & 57.61 & 4.66 & & & \\
\hline & $16-20 \mathrm{y} 1 \mathrm{l}$ & 36 & .92 & $.01^{*}$ & 40.14 & 4.00 & & & \\
\hline & 21 y1l ve üzeri & 23 & .79 & $.00 *$ & 57.83 & 4.66 & & & \\
\hline
\end{tabular}

$* p<.05$

Görüldüğü gibi strateji planlama, bilinçli seçim yapma, güven sağlama, öğrenciye 'yapamam' kelimesini yasaklama, öğrenci fikirlerini yansıtma, öğrenci davranışlarını tanımlama, öğrenci terminolojisini açığa kavuşturma, günlük tutma ve model olma boyutlarında kıdemlere göre anlamlı bir fark belirlenememiştir. Medyanlar incelendiğinde ise strateji planlama alt boyutunu, 0-5, 6-10, 16-20 yıl arası kıdeme sahip olan öğretmenlerin 'sık sık', 11-15 yıl, 21 yıl ve üzeri kıdeme sahip olan öğretmenlerin ise 'her zaman' kullandıkları belirlenmiştir. Bilinçli seçim yapma stratejisini, öğretmenlerin 'sık sık' ve 'bazen' kullandıkları görülmüştür. Güven sağlama staratejisini 0-5 yıl, ‘bazen’ 21 yıl ve üzeri kıdeme sahip olan öğretmenlerin 'sık sık' kullandıkları belirlenmiştir. Öğrenciye 'yapamam' kelimesini yasaklama staratejisini 0-5 yıl arası kıdeme sahip olan öğretmenlerin 'sık sık', 21 
y1l ve üzeri kıdeme sahip olan öğretmenlerin 'her zaman' kullandıkları saptanmıştır. Öğrenci fikirlerini yansıtma stratejisini 0-5 yıl, arası kıdeme sahip olan öğretmenlerin 'bazen', düzeyinde kullandıkları diğer kıdemlere sahip olanların ise 'sık sık' düzeyinde kullandıkları görülmüştür. Öğrenci davranışlarını tanımlama stratejisini ‘her zaman’ ve 0-5 yıl veya ‘sık sık kullandıkları görülmüştür. Görüldüğü gibi yine kıdem arttıkça stratejilerin kullanılma sıklığı artmaktadır. Öğrenci terminolojisini açığa kavuşturma stratejisini tüm kıdemlerde 'sık sık' kullanıldığı belirlenmiştir. Günlük tutma stratejisini 0-5 yıl arası kıdeme sahip olan öğretmenlerin hiç kullanmadıkları, diğer kıdemlere sahip olan öğretmenlerin ise, 'nadiren’ ya da'bazen' kullandıkları görülmüştür. Model olma stratejisini ise öğretmenlerin 'sık sık' veya 'her zaman' kullandıkları saptanmıştır.

Öğretmenlerin, öğrenme-öğretme sürecinde bilişsel farkındalık stratejilerini kullanma düzeylerinde, mesleki kıdem sürelerine göre fark olup olmadığını belirlemek amacıyla yapılan Kruskall Wallis testi sonucuna göre; 'Soru üretme ve 'drama yapma/rol oynama' stratejilerinde anlamlı fark bulunduğu tespit edilmiştir $(p<.05)$. Anlamlı farklılığın hangi gruplar arasında olduğunu belirlemek amacıyla, Mann Whitney U testi uygulanmış ve boyutlar tek tek değerlendirilmiştir.

Bununla beraber göre 'soru üretme' stratejisinde 0-5 yıl arası kıdeme sahip olanların 11-15 yıl ve 21 yıl ve üzeri arası kıdeme sahip olanlara göre, yine 6-10 yıl arası kıdeme sahip olanların 16-20 yıl ve 21 yıl ve üzeri kıdeme sahip olanlara göre, 11-15 yıl arası kıdeme sahip olanların 16-20 yıl ve 21 yıl ve üzeri arasında kıdeme sahip olan öğretmenlere göre daha fazla 'öğrencilerin ders öncesi ve ders sırasında kendi kendilerine sorular oluşturarak çalışmalarına teşvik etmeye yönlendirdikleri söylenebilir. 'drama yapma/rol oynama' stratejisinde ise; 0-5 yıl arası kıdeme sahip olan öğretmenlerin 16-20 yıl ve 21 yıl ve üzeri kıdeme sahip olanlara göre, 6-10 yıl arası kıdeme sahip olanların ise 11-15 yıl, 16-20 yıl, 21 yıl ve üzeri arası kıdeme sahip olanlara göre öğrencilerini; arkadaşlarının yerini alarak onların bilinçli olarak arkadaşlarının önemli karakteristik özelliklerini devam ettirmelerini sağlamaya daha fazla yönlendirdikleri söylenebilir. Dağılımın normal olduğu birden fazla ölçütle değerlendirme boyutunda kıdeme göre anlamlı farklılık bulunma durumu tek yönlü varyans analizi ile test edilmiştir. Elde edilen bulgular şöyledir. 
Ege Eğitim Dergisi 2017 (18) 2: 527-556

Ortaöğretim Öğretmenlerinin Öğrenme-Öğretme Sürecinde Bilişsel Farkındalık Stratejilerini Kullanma Düzeyleri

Tablo 8. Birden fazla ölçütle değerlendirme stratejilerinin kullanma düzeylerinin mesleki kldem değişkenine göre varyans analizi sonuçları

\begin{tabular}{|c|c|c|c|c|c|c|c|c|c|c|c|}
\hline \multirow{2}{*}{$\begin{array}{l}\text { Bilişsel } \\
\text { Farkındalık } \\
\text { Stratejisi }\end{array}$} & \multirow{2}{*}{$\begin{array}{l}\text { Mesleki } \\
\text { kıdem } \\
\text { süresi }\end{array}$} & \multirow[t]{2}{*}{$\mathrm{N}$} & \multicolumn{2}{|c|}{$\begin{array}{c}\text { Shapiro-Wilk } \\
\text { S-W }\end{array}$} & \multirow[t]{2}{*}{$\bar{X}$} & \multirow[t]{2}{*}{ SS } & \multicolumn{2}{|c|}{$\begin{array}{l}\text { Homojenlik } \\
\text { Levene Testi }\end{array}$} & \multicolumn{2}{|c|}{ ANOVA } & \multirow{2}{*}{$\begin{array}{l}\text { An. } \\
\text { Fark }\end{array}$} \\
\hline & & & S-W & $\mathrm{p}$ & & & Lev. & $\mathrm{p}$ & $\mathrm{F}$ & $\mathrm{P}$ & \\
\hline \multirow{5}{*}{$\begin{array}{l}\text { Birden } \\
\text { fazla } \\
\text { ölçütle } \\
\text { değerlendir } \\
\text { me }\end{array}$} & $0-5$ y1l & 12 & .93 & .42 & 2.80 & .86 & \multirow{5}{*}{.91} & \multirow{5}{*}{.46} & \multirow{5}{*}{1.89} & \multirow{5}{*}{.11} & \multirow{5}{*}{ - } \\
\hline & $6-10 \mathrm{y} 1 \mathrm{l}$ & 7 & .85 & .13 & 3.04 & .52 & & & & & \\
\hline & $11-15$ y1l & 19 & .94 & .26 & 3.40 & .86 & & & & & \\
\hline & 16-20 yil & 36 & .96 & .28 & 3.15 & .87 & & & & & \\
\hline & $\begin{array}{l}21 \text { yıl ve } \\
\text { üzeri yıl }\end{array}$ & 23 & .94 & .17 & 3.57 & .99 & & & & & \\
\hline
\end{tabular}

Yapılan varyans analizi sonucunda kıdeme göre anlamlı farklılık bulunmadığ gözlenmiştir $\quad\left(F_{(4-92)}=1.893 ; \quad p<.05\right)$. Birden fazla değerlendirme staratejisine ilişkin ortalamalar incelendiğinde; 0-5 y1l ve 6-10 y1l, 16-20 y1l arası k1deme sahip olan öğretmenlerin bu stratejiyi ‘bazen’, 11-15 yıl, 21 yıl ve üzeri kıdeme sahip olan öğretmenlerin ise ‘sık sık' düzeyinde kullandıkları görülmüştür.

Öğretmenlerin öğrenme-öğretme sürecinde bilişsel farkındalık stratejilerini kullanma düzeylerinde mezun olunan fakülte değişkeni açısından anlamlı bir fark olup olmadığını belirleyebilmek amacıyla öncelikle dağılımların normalliği Kolmogorov-Smirnov Z normal dağılım testi ile belirlenmiştir Fakülte değişkenine göre görüşlerin normal dağılım gösterdiği görülmüştür. Ayrıca levene testi sonuçlarına göre de varyansların homojen olduğu görülmüş ve bağımsız gruplar $\mathrm{t}$ testi sonuçları dikkate alınmıştır. Elde edilen bulgular şöyledir.

Tablo 9. Mezun olunan fakülte de ğişkenine göre bilişsel farkındalık stratejilerinin kullanılma dïzeyleri

\begin{tabular}{|c|c|c|c|c|c|c|c|c|c|c|c|}
\hline \multirow[t]{2}{*}{ Fakülte } & \multirow[t]{2}{*}{$\mathrm{N}$} & \multicolumn{2}{|c|}{$\begin{array}{l}\text { Kolmogorov- } \\
\text { Smirnov Z }\end{array}$} & \multirow[t]{2}{*}{$\bar{X}$} & \multirow[t]{2}{*}{ SS } & \multirow[t]{2}{*}{ sd } & \multicolumn{2}{|c|}{$\begin{array}{l}\text { Homojenlik } \\
\text { Levene Testi }\end{array}$} & \multicolumn{2}{|c|}{ t testi } & \multirow{2}{*}{$\begin{array}{l}\text { An. } \\
\text { Fark }\end{array}$} \\
\hline & & K-S & $\mathrm{p}$ & & & & $\mathrm{F}$ & $p$ & $\mathrm{t}$ & $\mathrm{p}$ & \\
\hline Fen-Edb. F. & 44 & .11 & .20 & 3.69 & .59 & 00 & 175 & 17 & 15 & 85 & \\
\hline Eğitim F. & 48 & .06 & .20 & 3.73 & .55 & 90 & & .17 & 15 & .85 & - \\
\hline
\end{tabular}

Tabloda da görüldüğü gibi gruplar arasında anlamlı farklılık bulunamamıştır $\left(t_{(90)}=1.159 ; p>.05\right)$. Grupların ortalamalarına bakıldığına gerek Eğitim Fakültesi gerekse FenEdebiyat Fakültesi mezunu olan öğretmenlerin, bilişsel farkındalık stratejilerini 'sık sık' kullandıkları söylenebilir. Öğretmenlerin fakülte değişkenine göre bilisel farkındalık stratejilerinin alt boyutları arasında anlamlı farklılık olma durumuna ilişkin veriler Tablo 10 ' da verilmiştir. 
Ege Eğitim Dergisi 2017 (18) 2: 527-556

Ortaöğretim Öğretmenlerinin Öğrenme-Öğretme Sürecinde Bilişsel Farkındalık Stratejilerini Kullanma Düzeyleri

Tablo 10. Mezun olunan fakülte değisskenine göre alt boyutların kullanılma düzeyleri

\begin{tabular}{|c|c|c|c|c|c|c|c|c|}
\hline \multirow{2}{*}{$\begin{array}{l}\text { Bilişsel Farkındalık } \\
\text { Stratejileri }\end{array}$} & \multirow{2}{*}{$\begin{array}{l}\text { Fakülte } \\
\text { Değişkeni }\end{array}$} & \multirow[t]{2}{*}{$\mathrm{N}$} & \multicolumn{2}{|c|}{$\begin{array}{l}\text { Kolmogorov- } \\
\text { Smirnov }\end{array}$} & \multirow{2}{*}{$\begin{array}{l}\text { Sira } \\
\text { Ort. }\end{array}$} & \multirow[t]{2}{*}{ Medyan } & \multicolumn{2}{|c|}{$\begin{array}{c}\text { Mann Whitney U } \\
\text { Testi }\end{array}$} \\
\hline & & & $\mathrm{K}-\mathrm{S}$ & $\mathrm{p}$ & & & $\mathrm{U}$ & $\mathrm{p}$ \\
\hline \multirow{2}{*}{ Soru üretme } & Fen-Edb.F. & 44 & .17 & $.00 *$ & 48.36 & 3.75 & \multirow{2}{*}{974.00} & \multirow{2}{*}{.5} \\
\hline & Eğitim F. & 48 & .28 & $.00 *$ & 44.79 & 4.00 & & \\
\hline \multirow{2}{*}{ Bilinçli seçim yapma } & Fen-Edb.F. & 44 & .17 & $.00 *$ & 44.67 & 4.25 & \multirow{2}{*}{975.50} & \multirow{2}{*}{.52} \\
\hline & Eğitim F. & 48 & .16 & $.00 *$ & 48.18 & 3.87 & & \\
\hline \multirow{2}{*}{$\begin{array}{l}\text { Birden fazla ölçütle } \\
\text { değerlendirme }\end{array}$} & Fen-Edb.F. & 44 & .16 & $.00 *$ & 47.33 & 4.25 & \multirow{2}{*}{1019.50} & \multirow{2}{*}{.77} \\
\hline & Eğitim F. & 48 & .12 & .06 & 45.74 & 36.83 & & \\
\hline \multirow{2}{*}{ Güven sağlama } & Fen-Edb.F. & 44 & .15 & $.01 *$ & 46.82 & 58.29 & \multirow{2}{*}{1042.00} & \multirow{2}{*}{.91} \\
\hline & Eğitim F. & 48 & .16 & $.00 *$ & 46.21 & 57.26 & & \\
\hline \multirow{2}{*}{$\begin{array}{l}\text { Öğrenciye ‘yapamam’ } \\
\text { kelimesini yasaklama }\end{array}$} & Fen-Edb.F. & 44 & .14 & $.02 *$ & 44.05 & 38.32 & \multirow{2}{*}{948.00} & \multirow{2}{*}{.39} \\
\hline & Eğitim Fak. & 48 & .16 & $.00 *$ & 48.75 & 62.41 & & \\
\hline \multirow{2}{*}{$\begin{array}{l}\text { Öğrenci fikirlerini } \\
\text { yansıtma }\end{array}$} & Fen-Edb.F. & 44 & .16 & $.00 *$ & 47.20 & 48.83 & \multirow{2}{*}{1025.00} & \multirow{2}{*}{.80} \\
\hline & Ĕ̆itim F. & 48 & .13 & $.02 *$ & 45.85 & 46.57 & & \\
\hline \multirow{2}{*}{$\begin{array}{l}\text { Öğrenci davranışlarını } \\
\text { tanımlama }\end{array}$} & Fen-Edb.F. & 44 & .16 & $.00 *$ & 49.75 & 59.13 & \multirow{2}{*}{913.00} & \multirow{2}{*}{.25} \\
\hline & Eğitim F. & 48 & .18 & $.00 *$ & 43.52 & 40.43 & & \\
\hline \multirow{2}{*}{$\begin{array}{l}\text { Öğrenci terminolojisini } \\
\text { açı̆̆a çıkarma }\end{array}$} & Fen-Edb.F. & 44 & .15 & $.00 *$ & 47.48 & 54.87 & \multirow{2}{*}{1013.00} & \multirow{2}{*}{.73} \\
\hline & Eğitim F. & 48 & .21 & $.00 *$ & 45.60 & 50.67 & & \\
\hline \multirow{2}{*}{$\begin{array}{l}\text { Drama yapma/rol } \\
\text { oynama }\end{array}$} & Fen-Edb.F. & 44 & .16 & $.00 *$ & 47.43 & 53.21 & \multirow{2}{*}{1015.00} & 74 \\
\hline & Eğitim F. & 48 & .13 & $.02 *$ & 45.65 & 45.58 & & .14 \\
\hline & Fen-Edb.F. & 44 & .10 & .20 & 44.92 & 46.26 & & \\
\hline Gunluk tutma & Eğitim Fak. & 48 & .14 & $.01 *$ & 47.95 & 53.96 & 986.50 & .58 \\
\hline & Fen-Edb.F. & 44 & .15 & $.00 *$ & 45.43 & 31.71 & & \\
\hline Model olma & Eğitim F. & 48 & .17 & $.00 *$ & 47.48 & 50.43 & 1009.00 & .71 \\
\hline
\end{tabular}

$* p<.05$

Öğretmenlerin mezun oldukları fakülte türüne göre alt boyutlara ilişkin bilişsel farkındalık düzeylerini kullanma görüşlerini karşılaştırmak için öncelikle dağılımların normalliği Kolmogorov-Smirnov Z testi ile analiz edilmiştir. Buna göre 'strateji planlama' alt boyutu dışındaki alt boyutlarda fakülte değişkenine göre görüşlerde dağılımın normal olmadığı belirlenmiştir. Buna göre parametrik olmayan testlerden Mann Whitney U testi kullanılmıştır. Elde edilen sonuca göre grupların alt boyutlara ilişkin görüşleri arasında anlamlı bir farklılık belirlenmemiştir ( $p>.05)$. Buna göre sıra ortalamalarına bakıldığında FenEdebiyat Fakültesi mezunu olan öğretmenlerin 'soru üretme, birden fazla ölçütle değerlendirme, güven sağlama, öğrenci fikirlerini yansıtma, öğrenci davranışlarını tanımlama, öğrenci terminolojisini açı̆̆a kavuşturma, drama yapma/rol oynama' stratejilerinde Eğitim Fakültesi mezunu olan öğretmenlere göre sıra ortalaması yüksek olmasına rağmen farkın istatistiksel olarak anlamlı olmadığı belirlenmiştir. Medyanlar incelendiğinde ise bilişsel stratejilerin alt boyutlarından soru üretme, bilinçli seçim yapma, öğrenci fikirlerini yansıtma, öğrenci davranışlarını tanımlama, öğrenci terminolojisini açı̆̆a kavuşturma, 'model olma stratejilerini Fen-Edebiyat Fakültesi ve Eğitim Fakültesi mezunu olan öğretmenlerin 'sık s1k' kullandıkları saptanmıştır. Birden fazla ölçütle değerlendirme staratejisini Fen-Edebiyat Fakültesi ve Eğitim Fakültesi mezunu olan öğretmenlerin 'bazen' kullandıkları tespit 
edilmiştir. Güven sağlama stratejisini Fen-Edebiyat Fakültesi mezunu öğretmenlerin 'bazen' Eğitim Fakültesi mezunu olan öğretmenlerin ise 'sık sık' kullandıkları belirlenmiştir. Öğrenciye yapamam kelimesini yasaklama stratejisini Fen-Edebiyat Fakültesi mezunu öğretmenlerin 'sık sık' Eğitim Fakültesi mezunu olan öğretmenlerin ise 'her zaman' kullandıklanı belirlenmiştir. Drama yapma/rol oynama Fen-Edebiyat Fakültesi mezunu öğretmenlerin ‘sık sık’ Eğitim Fakültesi mezunu olan öğretmenlerin ise ‘bazen' kullandıkları belirlenmiştir. Günlük tutma stratejisini Fen-Edebiyat Fakültesi ve Eğitim Fakültesi mezunu olan öğretmenlerin 'nadiren' kullandıkları görülmüştür. Starateji planlama stratejisinde öğretmenlerin fakülte düzeylerindeki görüşleri normal dağılım gösterdiği ve varyansların homojen olduğu belirlendiği için bağımsız gruplar t-testi yapmıştır. Elde edilen sonuçlar şöyledir.

Tablo 11. Mezun olunan fakülte değişkenine göre strateji planlama stratejilerinin kullanılma düzeyi

\begin{tabular}{|c|c|c|c|c|c|c|c|c|c|c|c|}
\hline \multirow{3}{*}{$\begin{array}{c}\text { Bilişsel } \\
\text { Farkındalık } \\
\text { Stratejisi }\end{array}$} & \multirow{3}{*}{$\begin{array}{c}\text { Fakülte } \\
\text { Değişkeni }\end{array}$} & \multirow{3}{*}{$\mathrm{N}$} & \multicolumn{3}{|c|}{ Kolmogorov- } & \multirow{3}{*}{ SS } & \multirow{3}{*}{$\mathrm{sd}$} & \multicolumn{2}{|c|}{ Homojenlik } & \multicolumn{2}{|c|}{$\mathrm{t}$ testi } \\
\hline & & & \multicolumn{2}{|c|}{ Smirnov Z } & $\bar{X}$ & & & Leven & Testi & & \\
\hline & & & K-S & $\mathrm{p}$ & & & & $\mathrm{F}$ & $\mathrm{p}$ & $\mathrm{t}$ & $\mathrm{p}$ \\
\hline \multirow{2}{*}{$\begin{array}{c}\text { Strateji } \\
\text { planlama }\end{array}$} & Fen-Edb. F. & 44 & .11 & .13 & 3.94 & .71 & \multirow{2}{*}{90} & \multirow{2}{*}{1.300} & \multirow{2}{*}{.257} & \multirow{2}{*}{.005} & \multirow{2}{*}{.996} \\
\hline & Eğitim F. & 48 & .11 & .08 & 3.94 & .58 & & & & & \\
\hline
\end{tabular}

Buna göre gruplar arasında anlamlı farklılıklar bulunamamıştır $\left(t_{(90)}=.005 ; p>.05\right)$. Grupların ortalamaları dikkate alndığında ise Eğitim Fakültesi ve Fen-Edebiyat Fakültesi mezunu olan öğretmenlerin 'starateji planlama' stratejilerini 'sık sık' düzeyinde kullandıkları görülmüştür. Buna göre gerek Eğitim Fakültesi gerekse Fen-Edebiyat Fakültesi mezunu olan öğretmenlerin, öğrencilerini herhangi bir faaliyet öncesinde, kullanacakları stratejiye, karşılaşabileceği sorunlara ve hatırlanması gereken kurallara dikkat çekmeye teşvik ettikleri söylenebilir.

\section{Sonuç Tartışma ve Öneriler}

Yapılan araştırma sonuçlarına göre araştırmaya katılan erkek öğretmenlerin, kadın öğretmenlerden fazla olduğu, öğretmenlerin mesleki kıdem sürelerinin 16-20 yıl arasında olduğu ve eğitim fakültesi mezunlarının daha fazla olduğu görülmüştür.

Araştırma sonucuna gore öğretmenler; öğrenme-öğretme sürecinde bilişsel farkındalık stratejilerini 'sık sık' düzeyinde kullanmaktadırlar. $\mathrm{Bu}$ sonuç oldukça olumludur. Öğretmenlerin etkili bir öğrenme-öğretme ortamı oluşturabilmelerini sağlayacak öğretmenlik becerilerine sahip olması için bilişsel stratejilerin katkısı büyüktür. Yapılan pek çok 
araştırmada bu doğrultudadır. Bilişötesi stratejileri kullanan öğretmenlerin öğrencilerle daha yakından ilgilendikleri, etkili öğretim için farklı yaklaşımlar kullandıkları, öğrencilerin öğrenmeleri için daha fazla çaba ve zaman harcadıkları, daha fazla sorumluluk hissettikleri ve yüklendikleri (Yılmaz ve Çokluk Bökeoğlu, 2008) yapılan araştırmalarda görülen olumlu sonuçlardandır. Alt boyutlar açısından bakıldığında ise araştırmaya katılan öğretmenlerin, en çok"öğrenciye yapamam kelimesini yasaklama" stratejisini kullandıkları en az ise "günlük tutma" stratejisini kullandıkları görülmektedir.

Araştırmada öğretmenlerin cinsiyetlerinin öğrenme-öğretme sürecinde bilişsel farkındalık stratejilerini kullanma düzeylerini etkilemediği görülmüştür. Alanyazın ilgili bulgu açısından incelendiğinde, yapılan pek çok çalışmanın (Aydın ve Coşkun, 2011; Çakıroğlu ve Kuruyer, 2010; Dilci ve Kaya, 2012; Memnun ve Akkaya, 2009; Özsoy, Özsoy ve Günindi, 2011;) bu sonucu desteklediği, cinsiyetin bilişötesi öğrenme stratejilerinin kullanımına etki etmediği görülmüştür. Bu çalışmanın aksine cinsiyetin bilişötesi öğrenme stratejilerinin kullanımına etki ettiğini gösteren çalışmalarda vardır. Örneğin Tunca ve Alkın Şahin'in (2014) yaptığı çalışmada, kadın öğretmen adaylarının ortalamalarının erkek öğretmen adaylarından daha yüksek olduğu yani kadın öğretmen adaylarının bilişötesi öğrenme stratejilerini erkek öğretmen adaylarına göre daha çok kullandıkları sonucuna ulaşılmıştır.

Cinsiyete göre alt boyutlara bakıldığında ise kadın öğretmenler, 'soru üretme, güven sağlama, öğrenci davranışlarını tanımlama, model olma’ stratejilerini erkek öğretmenlere göre daha fazla kullanmaktadırlar. Araştırmaya katılan erkek öğretmenlerin oransal olarak daha fazla olmasına rağmen, sonucun kadın öğretmenler lehine çıkması dikkat çekicidir. Bu durum, kadın öğretmenlerin bilişsel farkındalık stratejilerini, öğretme-öğrenme sürecinde erkek öğretmenlere oranla daha fazla kullandıklarını göstermektedir. Öğrenci fikirlerini yansıtma stratejisini erkek öğretmenler kadın öğretmenlere göre daha fazla kullanmaktadırlar. Yıldırım (2012) araştırmasında ise bu bulgu kadın öğretmenler lehine çıkmıştır. Yıldırım, kadın öğretmenlerin, öğrenme-öğretme sürecinde öğrenci fikirlerini yansıtma boyutunu erkek öğretmenlere göre daha fazla kullandıklarını tespit etmiştir. Strateji planlama, bilinçli seçim yapma, öğrenci terminolojisini açığa çıkarma stratejilerini erkek ve kadın öğretmenler aynı düzeyde sık sık kullanmaktadırlar. Bu bulgu Aydın'ın (2012) araştırmasında kadın öğretmenler lehine çıkmıştır. Güven sağlama stratejisini kadın öğretmenler sık sık, erkek öğretmenler ise bazen kullanmaktadırlar. 
Öğretmenlerin mezun oldukları fakülte türü öğrenme-öğretme sürecinde bilişsel farkındalık stratejilerini kullanmalarını etkilememektedir. Bu çalışmanın aksine fakülte türünün bilişötesi öğrenme stratejilerinin kullanımına etki ettiğini gösteren çalışmalarda vardır. Örneğin Yıldırım (2012, s.96) ve Kazu ve Yıldırım (2013, s.13) tarafından yapılan çalışmalarda 'öğrenci davranışlarını tanımlama' ve 'model olma' boyutlarında fakülte türüne göre anlamlı fark bulduğunu ifade etmiş̧tir. Bu araştırmaya göre ise fen edebiyat fakültesi veya eğitim fakültesi mezunu olmanın öğretmenlerin bilişsel stratejileri kullnama düzeyini etkilemediği görülmüştür.

Mesleki kıdem değişkeni açısından ise; genel olarak mesleki kıdem süresi fazla olan öğretmenler, az olan öğretmenlere göre daha fazla bilişsel farkındalık stratejisi kullanmaktadırlar. $\mathrm{Bu}$ durumun, öğretmenlerin mesleğe yeni başlamalarına bağlı olarak tecrübe eksikliğinden kaynaklandığı söylenebilir. Bu sonucu alan yazındaki pek çok çalışma desteklemektedir. Özcan (2007) yaptı̆̆ı araştırmada, öğretmenlerin meslekte geçirdikleri süre ile derslerinde biliş üstü becerileri geliştiren stratejileri kullanma arasında anlamlı bir fark olduğunu tespit etmiştir. Araştırma sonucunda; mesleki tecrübesi 1-5 yıl arası olan öğretmenlerin mesleki tecrübesi 5 yıldan fazla olan öğretmenlere göre, derslerinde biliş üstü becerileri geliştiren stratejileri daha az kullanmakta olduğunu belirlemiştir. Pinnegar (1993) yaptığı çalışmasında; mesleğe yeni başlayan öğretmenlerin olaylara yüzeysel bakmakta, gereksiz ayrıntılara takılarak bütünü kaçırmakta oldukları ve ayrıca bilgilerini nasıl ve nerede kullanacakları konusunda güçlük çekmekte olduklarını belirlemiştir (Akt. Kazu ve Yıldırım, 2013, s.13). Alt boyutlar açısından mesleki kıdem, soru sorma ve drama yapma/rol oynama stratejilerini etkilemektedir. Bu bulgu Doğanay ve Öztürk'ün (2011, s.1317) bilişsel farkındalık açısından deneyimli ve deneyimsiz sınıf öğretmenlerinin fen ve teknoloji dersi öğretim süreçlerinin farklılık gösterip göstermediğini inceledikleri araştırma sonucuyla benzerlik göstermektedir. Elde edilen sonuçlar incelendiğinde, deneyimli ve deneyimsiz sınıf öğretmenlerinin fen ve teknoloji dersi öğretim süreçlerinin bilişsel farkındalık açısından önemli derecede farklılaştığı ortaya çıkmıştır.

Bilişötesi öğrenme stratejilerinin kullanımı öğrenci başarısını arttırdığı bilinmektedir (Çalışkan ve Sünbül, 2011; Doğanay ve Demir, 2011; Özkal ve Çetingöz, 2006). Öğrencilerin bilişsel farkındalık stratejilerini kullanma düzeylerine yönelik yapılan araştırmalar kadar öğretmenlere yönelik olarak da bu tip araştırmalara ağırlık verilmelidir. Öğretmenlere, bilişsel farkındalık stratejilerinin neler olduğu ve öğrenme-öğretme sürecinde sağlayacağı faydalara yönelik olarak MEB tarafından düzenlenen hizmet içi eğitim kursları bünyesinde 
eğitimler düzenlenebilir. Kıdem süresi daha düşük olan öğretmenlerin öğrenme-öğretme sürecinde bilişsel stratejilerin neden daha az kullandıklarına yönelik araştırmalar yapılabilir. Bunun yanı sıra öğretmenlerin öğrenme-öğretme sürecinde 'günlük tutma' stratejisini en az düzeyde kullandıkları görülmüştür. Günlük tutma stratejisi düşünceleri ve olayları sentezleme ve sembolik formlara dönüştürme özelliklerini içerdiğinden kazanılması yerinde bir stratejidir. Öğretmenlerin bu stratejiyi kullanmayı neden daha az tercih ettiklerine yönelik araştırmalar yapılabilir. Öğrenme-öğretme sürecinde bilişsel farkındalık stratejilerinin kullanılma düzeyine ilişkin farklı illerde de araştırmalar yapılarak bu tip araştırmaların genellenebilirliği tartışılmalıdır. 


\section{Kaynakça}

Artzt, A. F. ve Armour-Thomas, E. (1998). Mathematics teaching as problem solving: a framework for studying teacher metacognition underlying: Instructional practice in

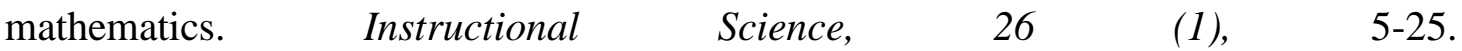
http://link.springer.com/article/10.1023\%2FA\%3A1003083812378 adresinden elde edildi.

Ashman A. ve Conway R. (1993). Using cognitive methods in the Classroom. London: Routledge.

Aydın, F. ve Coşkun, M. (2011). Geography teacher candidates' metacognitive awareness levels: A case study from turkey. Archives of Applied Science Research, 3 (2), 551557.

Baykara, K. (2011). Öğretmen adaylarının bilişötesi öğrenme stratejileri ile öğretmen yeterlilik algıları üzerine bir çalışma. Hacettepe Üniversitesi Ĕ̆gitim Fakültesi Dergisi 40, 80-92.

Bedir, H. (1996). The effects of using cognitive learning strategies on reading comprehension ability of turkish student. (Yayımlanmamış Doktora Tezi). Çukurova Üniversitesi. Adana.

Boyacı, M. (2010). Ortä̈ğretim öğrencilerinin temel yetenek düzeyleri ile bilişötesi öğrenme stratejileri arasındaki ilişki. (Yayımlanmamış Yüksek Lisans Tezi). Gaziosmanpaşa Üniversitesi. Tokat.

Büyüköztürk, Ş., Akgün, Ö., Karadeniz, Ş., Demirel, F. ve Kılıç, E.(2016). Bilimsel araştırma yöntemleri. (22. Baskı) PegemA Yayıncılık Ankara.

Çalışkan, M ve Sünbül, A.M. (2011). Öğrenme stratejileri öğretiminin yürütücü biliş bilgisine, yürütücü biliş becerilerini kullanmaya ve başarıya etkisi: ilköğretim 6. sınıf türkçe dersi örneği. Kuram ve Uygulamada Ĕ̆itim Bilimleri, 11(1), 133-153.

Dilci, T., ve Kaya, S. (2012). 4. ve 5. sınıflarda görev yapan sınıf öğretmenlerinin üstbilişsel farkındalık düzeylerinin çeşitli değişkenler açısından incelenmesi. Sosyal Bilimler Dergisi, 27, 247-267.

Doğanay, A. ve Demir, Ö. (2011). Akademik başarısı düşük ve yüksek öğretmen adaylarının ders çalışma sırasında bilişsel farkındalık becerilerini kullanma düzeylerinin karşılaştırılması, Kuram ve Uygulamada Ĕ̆itim Bilimleri, 11(4), 2021-2043. 
Doğanay, A., ve Öztürk, A. (2011). Deneyimli ve deneyimsiz sınıf öğretmenlerinin bilişsel farkındalıkları açısından fen ve teknoloji dersi öğretim süreçlerinin incelenmesi. Kuram ve Uygulamada Eğitim Bilimleri, 11 (3), 1301-1325.

Ektem Sönmez, I. (2007). lköğretim 5. sinıf matematik dersinde uygulanan yürütücü biliş stratejilerinin öğrenci erişi ve tutumlarına etkisi. (Yayımlanmamış Doktora Tezi). Selçuk Üniversitesi, Konya.

Forrest-Pressley, D. L. ve Waller, T. G. (1984). Cognition, metacognition and reading. New York: Springer-Verlag.

Forrest-Pressley, MacKinnon, G.E. ve Waller, T.G. Metacognition, Cognition, and Human Performance, Theoretical Perspectives. (volume 1). Academic Press, Inc.

Gavelek, J. R., Raphael, T. E. (1985). Metacognition, instruction, and questioning. In D. L. Forrest-Pressley, G.E.

Gelen, . (2003). Bilişsel farkındalık stratejilerinin türkçe dersine ilişkin tutum, okuduğunu anlama ve kalıcılığa etkisi. (Yayımlanmamıs Doktora Tezi). Çukurova Üniversitesi. Adana.

Göçmen, A. 2003. Yeniden öğrenme. Ankara: Nobel Yayın Dağıtım.

Hacker, D. J. (1998), Metacognition in educational theory and practice. çinde In D. J. Hacker, J. Dunlosky, and A. C. Graesser (eds.), Metacognition: Definitions and empirical foundations. Mahwah, NJ.: Erlbaum.

Hartman H.J. (2002). Metacognition in learning and instruction. Theory, research and practice. U.S.A: Kluwer Akademic Publishers.

Kazu, H.\&Yıldırım, N. (2013). Öğretmenlerin bilişsel farkındalık stratejilerini kullanma düzeylerinin çeşitli değişkenler açısından karşılaştırılması. Türk Ĕ̆gitim Bilimleri Dergisi. 11(4), 1-19.

Lories G. ve Dardenne B. ve Yzerbyt V. Y. (1998). Metacognition. cognitive and social dimensions. London: Sage publications.

Marzano, R. J., Brandt, R., Hughes, C., Jones, B., Presseisen, B., Rankin, S., ve Suhor, C. (1988). Dimensions of thinking: A framework for curriculum and instruction. Alexandria, VA: Association for Supervision and Curriculum Development. 
Memnun, D.S. ve Akkaya, R. (2009). The levels of metacognitive awareness of primary teacher trainees. Procedia Social and Behavioral Sciences, 1, 1919-1923.

Onbaş1, D. (2015). Ortaöğretim fen ve teknoloji öğretmenlerinin öğretme-öğrenme süreçlerinde uyguladıkları bilişsel farkındalık stratejilerinin incelenmesi. (Yayımlanmamış Yüksek Lisans Tezi). Doğu Akdeniz Üniversitesi. Gazimağusa, Kuzey Kıbrıs Türk Cumhuriyeti.

Özcan, Z. Ç. (2007). Sınıf Ö ̆̆retmenlerinin derslerinde biliş üstü beceri geliştiren stratejileri kullanma özelliklerinin incelenmesi. (Yayımlanmamış Doktora Tezi). Marmara Üniversitesi Eğitim Bilimleri Enstitüsü, stanbul.

Özkal, N. ve Çetingöz, D. (2006). Akademik başarı, tutum ve öğrenme stratejilerinin kullanımı, Kuram ve Uygulamada Ĕ̈itim Yönetimi, 46, 259-275.

Özsoy, G. ve Günindi, Y. (2011). Okulöncesi öğretmen adaylarının üstbilişsel farkındalık düzeyleri. lköğretim Online Dergisi, 10, 2, 430-440.

Özsoy, G., Çakıroğlu, A., ve Kuruyer, G. H. (2010). Sınıf öğretmeni adaylarının üstbilişsel farkındalık düzeylerinin bazı değişkenler bakımından incelenmesi. Sözel bildiri, 9. Sınıf Öğretmenliği Eğitimi Sempozyumu, Elezı̆̆.

Öztürk, A. (2009). Fizik problemlerini çözmede yüksek ve düşük başarılı fen ve teknoloji öğretmen adaylarının fizik problem çözme süreçlerinin bilişsel farkındalık açısından incelenmesi. (Yayımlanmamı̧ Yüksek Lisans Tezi). Çukurova Üniversitesi. Adana.

Tunca, N. ve Alkın Şahin, S. (2014). Öğretmen adaylarının bilişötesi (üst biliş) öğrenme stratejileri ile akademik öz yeterlik inançları arasındaki ilişki. Anadolu Journal of Educational Sciences International. 4(1) 47-56.

Weinert, F. E. (1987), Metacognition, motivation, and understanding, çinde. In F. E. Weinert and R. H. Kluwe (Eds). Metacognition and motivation as determinants of effective learning and understanding. Hillsdale, NJ: Lawrence Erlbaum.

Wellman, H. (1985). The origins of metacognition. In D. L.

Wilson, J. (1999). Defining metacognition: A step towards recognising metacognition as a worthwhile part of the curriculum. Sözel bildiri, Annual Meeting of the American Educational Research Association, Melbourne. 
Ege Eğitim Dergisi 2017 (18) 2: 527-556

Ortaöğretim Öğretmenlerinin Öğrenme-Öğretme Sürecinde Bilişsel Farkındalık Stratejilerini Kullanma Düzeyleri

Yıldırım, N. (2012). Öğretmenlerin öğrenme-öğretme ortamlarında bilişsel farkındalık stratejilerini kullanma düzeyleri. (Yayımlanmamış Yüksek Lisans Tezi). Fırat Üniversitesi. Elazı̆

Y1lmaz, K. ve Çokluk Bökeoğlu, Ö. (2008). lköğretim okulu öğretmenlerinin yeterlilik inançları. Ankara Üniversitesi Ĕ̆itim Bilimleri Fakültesi Dergisi. 41(2), 143-167. 


\section{Extended Abstract}

Metacognitive awareness which is subject to many research in the world since 1970s have also started to be discussed in the researches and has corresponded to various statements since 2000s in Turkey (Y1ldırım, 2012, p.3). Metacognitive awareness that could be used interchangeably can be defined as "a total of thought strategies" (Gelen, 2003, p.32) or "the way to use knowledge" (Bedir, 1996, p.55). Teachers help student learning with the methods they develop with their own experiences and knowledge in education and training process. In order for the teachers to improve the metacognitive awareness of their students they should first be aware of and use their own metacognitive awareness skills and know and use the learning strategies towards it. The aim of this research is to determine the metacognitive strategy usage levels of the secondary education teachers who attended to the in-service training titled "Learning-Teaching Theories and Approaches"organized by the Ministry of Education on March 21-25, 2016 in Mersin. According to this general aim, answers to the following questions have been searched for:

1. Do the teachers use all stages of metacognitive awareness strategies?

2. Does gender,

3. Seniority,

4. The faculty of graduation effect the usage of metacognitive awareness strategies in learning-teaching process?

The study is limited with the 97 secondary education teachers participated in the aforementioned in-service training and the data were obtained on their usage level of metacognitive awareness strategiesin learning-teaching process. Survey method has been used to define the usage level of metacognitive awareness strategies. The data were obtained via the 44 item scale prepared by Yildırım in 2012. Scale is composed of "strategy planning, question production, evaluation with more than one criteria, providing confidence, forbidding student's 'can't do' statement, students' reflection of their ideas, description of student behaviors, elucidating student terminology, role play/drama, diary keeping, being a model" dimensions (Y1ldırım, 2012, p. 57-60). In the data analysis Kolmogorov-Smirnov Z test (for participants over 30) and Shapiro Wilk analysis (for participants less than 30) were done to test the convenience of the data for normal distribution (Yıldırım, 2012; cited from Bircan et al.). As a result of these analysis parametric tests were used for normal distribution whereas nonparametric tests were used when the data was not normally distributed. Results of the research were as follows: The number of male teachers were more than female teachers. The 
seniority of teachers were between 16-20 years and most them were educational faculty graduation. According to the results, teachers use metacognitive awareness strategies "often" in learning-teaching process. As for dimensions; the most used dimension is "forbidding students' 'can't do statements (often)" whereas "diary keeping" is the least used dimension. Gender and the type of the faculty graduated did not signifcantly effect the usage levels of metacognitive awareness. As for seniority variable; teachers with more seniority use more metacognitive awareness strategies than teachers with less seniority. In terms of subdimensions; seniority significantly effected question production, drama/role play strategies. As for the sub-dimensions in terms of gender, female teachers used "question production, providing confidence, describing teacher behaviors" strategies more than male teachers. Reflecting student ideas strategy was used more by male teachers than female teachers. Male and female teachers use strategy planning, conscious choice making and elucidating student terminology use in the same levels (often). Providing confidence strategy was used "often" by female teachers whereas "sometimes" by male teachers. No significant difference was detected in terms of the type of faculty graduated. As a result, teachers participating in the study used metacognitive awareness strategies in learning-teaching process. The least used dimension was diary keeping. Gender, seniority and the type of faculty graduated variables did noteffect the usage levels of metacognitive awareness strategies. Studies on teachers' usage levels of metacognitive awareness strategies should also be concentrated on as much as those on students. In-service trainings about on metacognitive awareness strategies and their benefits in learning-teaching process can be organized by Ministry of Education. Research can be conducted on the reasons why teachers with shorter seniority use less metacognitive awareness strategies. Moreover, studies can be conducted on why teachers use diary keeping strategy less. The generalizability of research can be discussed by making research on usage levels of metacognitive awareness strategies in different provinces. 